[94]イソタクチックポリプロピレン無配向フィルムの 熱処理物の熱解析

(1966 年 12 月 16 日受理)

上出健二* ·真田昌彦*

\begin{abstract}
要 旨 イソタクチックポリブロピレン無配向フィルムの熱処理物を Differential Scanning Calorimetry (DSC) によって熱解析し，微細構造の熱処理による変化を解明するのを目的とした。分別物 4 種 (粘度平均分子量, $\left.\bar{M}_{v}=8.2 \times 10^{4} \sim 4.7 \times 10^{5}\right)$, 未分別物 $\left(\bar{M}_{v}=3.2 \times 10^{5}\right)$ およびきわめて低い分 子量物 $\left(\bar{M}_{v}=3.9 \times 10^{3}\right)$ を缹ブレス法で面内無配向フィルムに成形し，これを試料とした。なお，試料 の ○一シクロルペンゼン $\left(150^{\circ} \mathrm{C}\right)$ 溶夜の高分解能核磁気共鳴スペクトルからミクロタクチシティが分 子量に無関係にほぼ一定であることを確かめた。热処理方法として，1）試料を徐々に加熱して所定温 度に到達後急冷する方法 (年温法)，2）所定温度から室温まで徐冷する方法 (降温法)，3）一定温度 で加熱後急冷する方法 (等温法) の三つを用いた。熱媒体としてなたね油を用いると, 熱処理温度の上 升につれて 油がフィルム内に吸収され, 試料の結晶化度が熱処理によって增加すると, 逆にフィルム から渗出される。たたし，油の吸収は試料の融点低下を引き起こさないし，融解熱にも影響しない。試 料のもつ微細梏を融解直前までなるべく变化させず, その上, 測定時における感温部と試料との間の

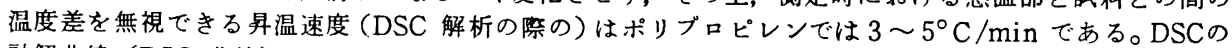
融解曲線 (DSC 曲線) から, 融解開始温度 $T_{m 1}$, 融解速度が最大となる温度 (ピーク温度) $T_{m 2}$, 融解 䅂了温度 $T_{m 3}$ を決定した。 $T_{m 3}$ は示差熱曲線のピーク温度にほぼ一致した。さらに十分結晶化が進んだ 試料の $T_{m 3}$ はディラトメトリーによって得られる融点とむよく一致した。分子量 $8 \times 10^{4}$ 以上ならば, $T_{m 2}, T_{m 3}$ は $150^{\circ} \mathrm{C}$ 以下の熱処理によっては変化しない。150 $170^{\circ} \mathrm{C}$ 熱処理によって $T_{m 2}, T_{m 3}$ は高温 にずれた。一般には $160 \sim 165^{\circ} \mathrm{C}$ 熱処理物が最高编点を与える。分子量が $10^{3}$ 程度ならば, 最高融点を 与える盜度は䄪 $10^{\circ} \mathrm{C}$ 低温にずれる。分別物は未分別物よりも融解温度幅が狭くなる。特に, 最高融 点をむつ熱处理物 (分別物) は非常に狭い温度域で融解する。 $150^{\circ} \mathrm{C}$ 以上の等温熱処理において, 融点 $\left(T_{m 2}, T_{m 3}\right)$ が処理時間とともに高温にずれ，ついで平衡値に近ついた。

$70^{\circ} \mathrm{C}$ 以上 $160^{\circ} \mathrm{C}$ (場合によっては $150^{\circ} \mathrm{C}$ ) 以下で熱処理されたフィルムの DSC 曲線は低温融解ピ 一クをもつ。このピークは熱処理方法, 加熟媒体, 処理時間, や試料の分子量とその分布に全く無関係 にポリプロピレンフィルムの上記熱処理条件に伴って発生した。低温ピーク温度は熱処理温度よりも数 ${ }^{\circ} \mathrm{C}$ 高温値をとる。低温ピークは, 低立体規則性度部分の融解, スメチカ晶の融解, $\beta$ 変態の融解, 熱 测定時の分解, 融解直前の無配向化などに原因しない。熱処理によって新しく形成された結晶領域の5 ち, 熱安定性がきわめて悪い（したがって，構造の不規則な）部分の融解が低温融解ピークとして観測 される。この結晶領域も高度にイソタクチック分子鎖からなり, 単斜晶系である。
\end{abstract}

\section{1. 緒言}

結晶性高分子物の力学的性質や高温に打ける寸法安定 性を向上させるために，高分子物を熱処理する操作が広 く一般に利用されている。熱処理に伴って変化する物性 としてきわめて定性的には，1）高分子物を成型賦形す る際に付加された残留ひずみの除去，2）２次結晶化の 促進と完結，3）融解温度の向上，4）融解温度幅の狭 化などがあげられる。たから，熱処理工程は高分子物の 分子運動特性を利用する工程であるともいえる。熱処理 は工学的には重要な操作であるにもかかわらず, 基礎物 性面からの系統的で詳細な研究は, ナイロン6, ポリエ チレンテレフタレートやポリビニルアルコールなど二三 の高分子物に限られている。特に, 今までの研究ではX

* 旭化成工業株式会社瀻維研究所（大阪府高柣市八丁 啜 11）
線回折, 赤外線吸収スペクトルなどの棈造化学的手段や 動的粘弾性の温度変化などのレオロジー的手段が主とし て利用され，対象とする高分子物も未分別物から特定の 条件で紡系された 1 種類の㵶維である場合がほとんどで ある。瀻維の微細構造は紡系, 延伸条件の微妙な変化に よって広範囲に変動する。さらに, 試料の分子量や分子 量分布, 分子構造 (分岐, 末端基, 立体規則性など) が 異なれば微細構造の紡系条件依存性も当然変わる。この 意味では, 熱処理機構を明らかにするためのモデルとし ては繊維はあまり適当ではない。また，上述の構造化学 的, レオロジー的研究手段によっては, 熱処理過程で重 要な役割を演ずると予測される規則性の比較的悪い微細 構造領域の熱举動が直接とらえられない欠点がある。

著者らはさきに1; ポリプロピレン繊維の熱応力を測定 し、㵶維に及ぼす熱処理効果の一端を明らかにした。一 方 $^{2},-130 \sim+100^{\circ} \mathrm{C}$ の温度域におけるポリプロピレン 
の分子運動性を比容, 比熱, 動的力学損失, 核磁気共鳴 微分吸収曲線の線幅, 赤外吸収ハンドなどの温度变化か ら検討した。これらの結果より、ポリプロピレンは広い 温度範囲にわたって結晶化する傾向があるために，熱処 理操作によってかなり広い範囲で物性, 微細構造が変化 することが期待された。

本論文では, 高分子物の融解現象を解析すればその結 晶領域の熱安定特性，したがって試料が過去に受けた熱 履歴特性を知ることができるのに着目して, 無配向イン タクチックポリプロピレンフィルムの熱処理物の熱解析 を行なった。なお，高分子物質の熱的性質の測定，特に 示差熱測定は近年しばしば行なわれるようになり，現在 までの研究成果は二三の総説 ${ }^{31,41}$ や教科書 ${ }^{51,6)}$ によくま とめられている。ポリプロピレン（主として無処理物） の融解現象もすでに多くの研究者によって報告されてい る(文献, 後出)。しかし, ポリプロピレンについては 熱解析の結論は研究者によって異なり，確実な知識はま だわずかである（3.参照）。対象とした試料がほとんど 末分別物で, 十分なキャラクタリゼーションが行なわれ ていないこと, 試料の形態やその調製法が報告者によっ て異なることなどが、結論が不一致の原因の一部であ る。試料の分子量とその分布，結晶化条件などによっ て, 結晶化速度や結晶組織が広範囲に変化するか ${ }^{7), 81}$ 熱解析を行ならときには試料の十分なキャラクタリゼー ションが必要である。本論文ではこの点に特に留意し た。熱解析のデータを解釈するためには熱解析以外融解 温度と熱曲線の形についてのみ検討した。融解熱につい ては, 別報9)において試料の微細棈造と関連つけて述べ る。

\section{2. 実験}

\section{1 試料の調鈛}

市販級ポリプロピレンの沸とら $n$-ヘブタン抽出残 分 $\left[135^{\circ} \mathrm{C}\right.$ デカリン溶夜の固有粘度 $[\eta]=2.77,[\eta]=1.10$ $\times 10^{-4} \bar{M}_{w}{ }^{0.8010)}$ より計算した粘度平均分子量 $\bar{M}_{v}=3.17$ $\times 10^{5}$, デカリンージブチカルビトール系によるカラ 么分別実験より求めた分子量分布の幅（重量平均分子量 と数平均分子量の比) $\left.\bar{M}_{w} / \bar{M}_{n}=3.5\right]$, および $p$-キシレ ーポリエチレングリュール系の分別沈殿法を利用して得 た分別物 4 種 $\left(\bar{M}_{v}=8.2 \times 10^{4} \sim 4.7 \times 10^{5}\right)$ を原試料とし た。さらに極めて低い分子量 $\left(\bar{M}_{v}=3.9 \times 10^{3}\right)$ をもつが 高度にイソタクチックな未分別物（キャラクタリゼーショ ンの詳細は既報11 で述べたので省略するが， $\bar{M}_{w} / \bar{M}_{n}<$ 1.5〜2.0で，分別物とほぼ同程度である）を利用した。

*1 試料を液体窒案中に投入すると試料の周囲の夜体 窒素が急激に気化し, 熱层導率の低い気体で試料が つつまれる。このため液体窒素中への投入が徐冷效 果しかもたないのであろう。

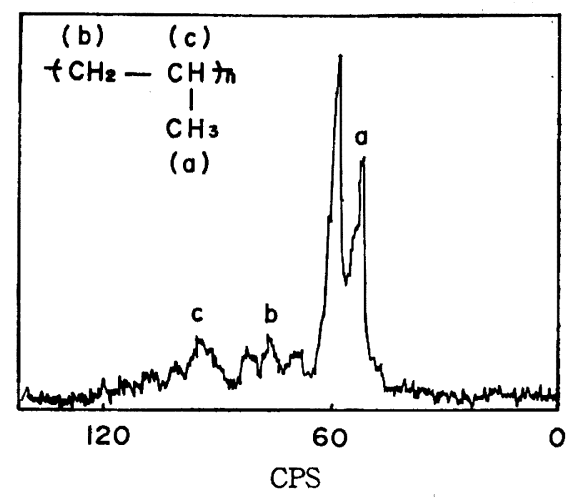

It is suggested from the chemical shifts of methylenic protons denoted as (b) in the figure that the degree of microtacticity is nearly the same for polymers ranging in molecular weight from $4 \times 10^{3}$ to $5 \times 10^{5}$.

Fig. 1. Representative high resolution nuclear magnetic resonance spectrum of specimen of isotactic polypropylene used in this study.

な拉、これらの原試料の立体規則性度をっージロルベ ンゼン溶液 $\left(150^{\circ} \mathrm{C}\right)$ の高分解核磁気共鳴吸収スペクル から推定した。測定例を Fig. 1 に示す。不斉炭素に隣 り合う主鎖に結合しているプロトン（メチレン基のブロ トン, Fig. 1 では(b)で表示) は 65〜 $78 \mathrm{cps}$ にわたっ て三つのピークに分離され，これらのピーク値の相対的 な関係は立体規則性度（いわゆるミクロタクチシティ） によって広い範囲に変化することが知られている(2) 17)。 本論文で使用した試料は, 分子量が 100 倍变化している のにかかわらず,（b ）に原因する化学シフトの碳細構造 は全く同一であった。したがって，立体規則性度は分子 量に依存せずほぼ一定であることが確められた。

原試料を $230^{\circ} \mathrm{C}$ で $3 \mathrm{~min}$ 加圧 $\left(20 \mathrm{~kg} / \mathrm{cm}^{2}\right)$ 溶融し, 引つづいて除圧して $1 \mathrm{~min}$ 静置後, これを

1） $-70^{\circ} \mathrm{C}$ に保たれているドライアイスーエタノール 浴に投入して，厚さ約 $0.1 \mathrm{~mm}$ の結晶成分としてはスメ チカ晶のみからなるフィルム（ $Q$ 試料）を得た。

2) 液体窒素中に投入して, 結晶成分としては単斜晶 のみからなる低比重徐冷フィルム（C陚料）を作っだ。 なおC試料は結晶形としては完全に単斜晶系のみからな ることをX線回折写真から確かめてある(文献 2 ) Table 2 参照)。

急冷, 徐冷フィルムはともに全く面内配向をしていな いことをX線回折と光学的複屈折度測定によってあらか しめ確かめた。Fig. 2 には1例として未分別フィルムの 急冷物之 $140^{\circ} \mathrm{C}$ 昇温処理物（窒素ガスふんい気）(処理 法の詳細は 2.2 参照) のフィルム面に平行にX線 $(\mathrm{Cu}-$ 


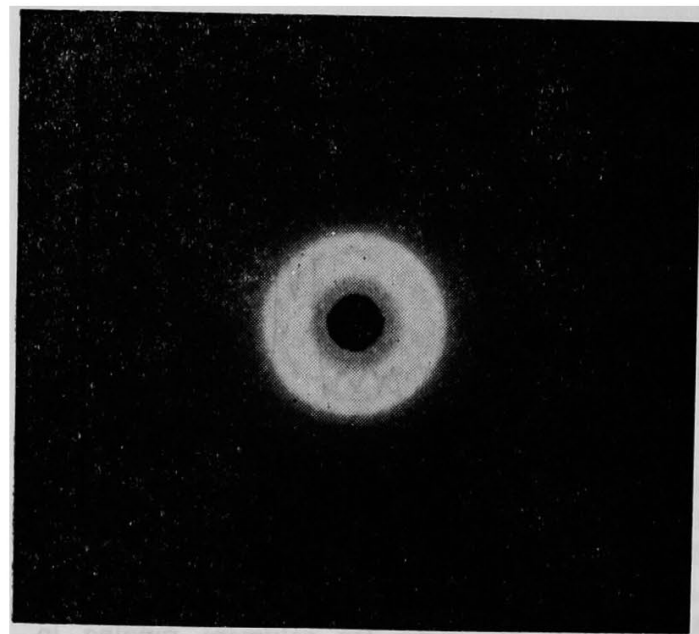

(a)

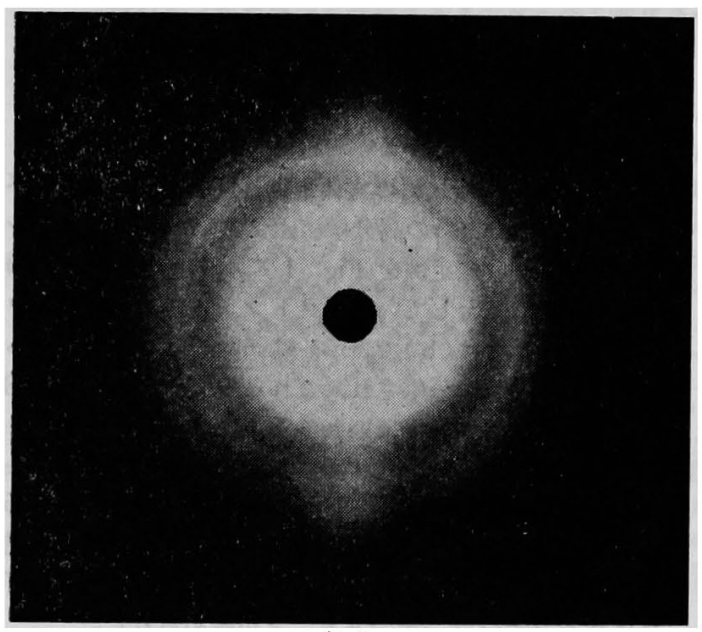

(b)

(a): Quenched films

(b): Films heat-treated up to $140^{\circ} \mathrm{C}$ by ascending temperature method in a nitrogen atmosphere.

$\mathrm{X}$-ray is beamed parallel to the surface of films which are made in layers. X-ray patterns do not show any evidence for uni-planar orientation of crystallites before and after the heat-treatment.

Fig. 2. X-ray diffraction diagrams for films of whole polymer molded by the follow. ing conditions; fusing temperature $230^{\circ} \mathrm{C}$, fusing time $3 \mathrm{~min}$.

$\mathrm{K}_{\alpha}$ 線）を入射した場合の回折写真を示す。

2.2 熱処理

2.2.1 戒温法熱处理
Q試料を窒素ガス浴または油浴(普通はなたね油浴)に 浸漬し, 室温より $0.5^{\circ} \mathrm{C} / \mathrm{min}$ の速度で昇温した。所定 の温度 (以後, この温度を熱処理温度とする) に到達後, 加熱浴より試料を取り出し，ただちにドライアイスーエ タノール浴に投入して急冷した。な扰ななた油を熱媒 体として利用する場合は熱処理フィルムの表面をエタ， ールで十分洗浄し，室温で真空乾燥した。

\subsection{2 降温法熱処理}

$0.5^{\circ} \mathrm{C} / \mathrm{min}$ の速度で鸰却されつつある熱浴にQ $\mathrm{Q}$ 試料 を所定の温度 (以後, この温度を熱処理温度とする) で 浸漬し、熱媒体が室温に冷却するまで浸漬をつづけた。

\subsection{3 等温熱処理}

所定の温度 $\left(120 \sim 170^{\circ} \mathrm{C}\right)$ 飞保たれた恒温槽に所定 の時間 (2 min〜 $570 \mathrm{~min}$ ) 浸漬し，熱処理後ただちに急 冷した。熟処理時間が $60 \mathrm{~min}$ 以内の場合, あらかじめ フィルムをアルミニウムはく（厚さ， $0.08 \mathrm{~mm}$ ）で密封 し,これを油の熱媒体中に直接浸漬した。

\subsection{4 熱媒体の勃果}

なたね油の中に直接浸漬して得られた, $100^{\circ} \mathrm{C}$ 以上の 熱処理物つ赤外吸収スペクトルは，ハントト $1745 \mathrm{~cm}^{-1}$ に 強く，するどい吸収をもち，その吸光度は処理温度をあ げると增加し，ある温度 $\left(155^{\circ} \mathrm{C}\right)$ で最大に達し，次い で急激に低下した（Fig．3）。熱処理物を沸とうアセト

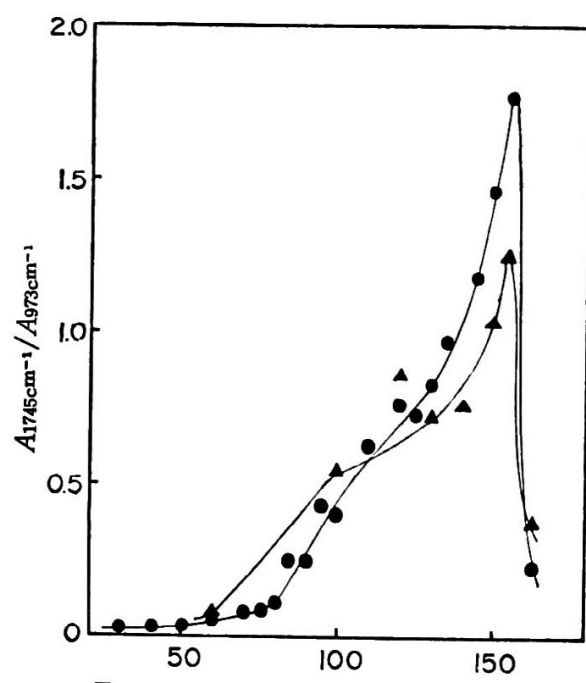

Temperature of heat-treatment $\left({ }^{\circ} \mathrm{C}\right)$

- Ascending temperature method in rapeseed oil.

$\Delta$ : Descending temperature method in rapeseed oil.

Fig. 3. Plots of ratio of absorbance band at $1745 \mathrm{~cm}^{-1}$ to that at $973 \mathrm{~cm}^{-1}$ (internal thickness band), $A_{1745 \mathrm{~cm}^{-1}} / A_{973 \mathrm{~cm}^{-1}}$ against the temperature of heat-treatment. 
Table 1. Effects of rape-seed oil absorption on melting points and heat of fusion.

\begin{tabular}{|c|c|c|c|c|c|c|c|c|}
\hline \multirow{3}{*}{$\begin{array}{l}\text { Temperature of } \\
\text { heat treatment } \\
\text { by ascending } \\
\text { temperature } \\
\text { method }\left({ }^{\circ} \mathrm{C}\right)\end{array}$} & \multirow{3}{*}{$\begin{array}{l}\text { Ratio of absorb- } \\
\text { ed oil to treated } \\
\text { film in weightal } \\
F\end{array}$} & \multirow{2}{*}{\multicolumn{3}{|c|}{$\begin{array}{c}\text { Melting points }{ }^{\mathrm{b})} \\
\text { for non-extracted } \\
\text { (extracted) film }\left({ }^{\circ} \mathrm{C}\right)\end{array}$}} & \multicolumn{3}{|c|}{ Heat of fusion (cal/g) } & \multirow{3}{*}{$\frac{\Delta H_{m}(I I)}{\Delta H_{m}(I)}(1-F)$} \\
\hline & & & & & \multirow{2}{*}{$\begin{array}{c}\Delta H_{m}(I) \\
\text { (for non- } \\
\text { extracted } \\
\text { film with } \\
\text { acetone }\end{array}$} & \multirow{2}{*}{$\begin{array}{l}\Delta H_{m}(I) \\
/(1-F)\end{array}$} & \multirow{2}{*}{$\left|\begin{array}{l}\Delta H_{m}(I I) \\
\text { (for ex- } \\
\text { tracted } \\
\text { film) }\end{array}\right|$} & \\
\hline & & $T_{m 1}$ & $T_{m 2}$ & $T_{m 3}$ & & & & \\
\hline 30 & 0.008 & $\begin{array}{c}132.8 \\
(131.7)\end{array}$ & $\begin{array}{c}163.2 \\
(163.2)\end{array}$ & $\begin{array}{c}171.1 \\
(170.5)\end{array}$ & 17.94 & 18.08 & 18.23 & 1.008 \\
\hline 60 & 0.010 & $\begin{array}{c}134.8 \\
(137.4)\end{array}$ & $\begin{array}{c}162.3 \\
(163.6)\end{array}$ & $\begin{array}{c}170.7 \\
(170.9)\end{array}$ & 17.63 & & 18.12 & - \\
\hline 100 & 0.058 & $\begin{array}{c}127.2 \\
(129.4)\end{array}$ & $\begin{array}{r}162.1) \\
(163.1)\end{array}$ & $\begin{array}{c}169.7 \\
(170.5)\end{array}$ & 17.63 & 18.72 & 18.91 & 1.010 \\
\hline 120 & 0.084 & $\begin{array}{c}110.8 \\
(107.5)\end{array}$ & $\begin{array}{c}162.6 \\
(163.2)\end{array}$ & $\begin{array}{c}170.7 \\
(170.7)\end{array}$ & 19.11 & 20.86 & 21.14 & 1.013 \\
\hline 130 & 0.087 & $\begin{array}{c}116.5 \\
(116.7)\end{array}$ & $\begin{array}{c}161.8 \\
(162.7)\end{array}$ & $\begin{array}{c}170.2 \\
(170.5)\end{array}$ & 19.33 & 21.17 & 21.03 & 0.993 \\
\hline 150 & 0.097 & $\begin{array}{c}135.0 \\
(135.6)\end{array}$ & $\begin{array}{c}161.0 \\
(162.6)\end{array}$ & $\begin{array}{c}170.5 \\
(170.9)\end{array}$ & 21.03 & 23.29 & 23.75 & 1.020 \\
\hline 160 & 0.020 & $\begin{array}{c}132.6 \\
(132.8)\end{array}$ & $\begin{array}{c}170.2 \\
(167.8)\end{array}$ & $\begin{array}{c}174.5 \\
(172.1)\end{array}$ & 23.47 & 23.95 & 25.83 & 1.079 \\
\hline
\end{tabular}

a) Values are determined by using extraction method with boiling acetone for $24 \mathrm{hr}$.

b) The definition of $T_{m 1}, T_{m 2}$, and $T_{m 3}$ should be referred to Fig. 4.

The above data suggest that rape-seed oil has almost negligible influence on melting behavior of polypropylene film and that no crystallization occurs during the extraction process.

ン, または沸とらェタノールで $24 \mathrm{hr}$ 抽出すれば, 1745 $\mathrm{cm}^{-1}$ の吸収は完全に消失する。さらに未抽出フィルム の吸光度比 $A_{1745 \mathrm{~cm}^{-1}} / A_{973 \mathrm{~cm}^{-1}}$ (ここで, $A_{1745 \mathrm{~cm}^{-1}}$, A973 $\mathrm{cm}^{-1}$ はおのおのパンド $1745 \mathrm{~cm}^{-1}, 973 \mathrm{~cm}^{-1}$ におけ る吸光度, $973 \mathrm{~cm}^{-1}$ は内部標準パンドでフィルムの厚 さ補正に利用した）は抽出量とは注直線関係にあって次 式で表わされる。

$A_{1745 \mathrm{~cm}^{-1}} / A_{973 \mathrm{~cm}^{-1}}=1.21 \times 10^{-1} \mathrm{C}$

たたし，Cはなたね油の抽出量（\%）である。

*2 むし，バンド $1745 \mathrm{~cm}^{-1}$ の吸収が高分子物の酸化 によって生じた CO 基に原因するのならば，1）吸 収がもっと幅広くなる，2）分子量低下を伴 5, 3）アセトンで抽出されない，4）処理温度ととも に吸光度はますはずである。

*3 溶融状態でなたね油と混合されたポリプロピレン の尉点は数 ${ }^{\circ} \mathrm{C}$ 低下する ${ }^{8)}$ 。

*4たとえば，なたね油中で界温法を利用して熱処理さ れた試料とその武料のアセトン抽出残の $A 997 \mathrm{~cm}^{-1} /$ $A_{973 \mathrm{~cm}^{-1}}$ の比を各熱処理温度に対して調へると $60^{\circ} \mathrm{C}(1.038), 100^{\circ} \mathrm{C}(0.992), 120^{\circ} \mathrm{C}(1.009)$, $130^{\circ} \mathrm{C}(1.040), 150^{\circ} \mathrm{C}(1.033)$ となる。
なたね油は $1745 \mathrm{~cm}^{-1}$ にするどい吸収をもつことと熱 処理物の分子量は低下していないこと，および熱処理の 進行につれて $A_{1745 \mathrm{~cm}^{-1}} / A_{973 \mathrm{~cm}^{-1}}$ がかえって堿少するこ となどの実験事実をあわせて考虑すれば，熱処理によっ てなたね油が約 $10 \%$ （重量基準）までポリプロピレンフ ィルムに吸収され，バンド $1745 \mathrm{~cm}^{-1}$ の吸収はなたね油 （おそらくはCO 基）に原因することが明らかであ る*2。

なたね油を吸収した熱処理物の融解挙動を調べると, 融点はなたね油を抽出した残りの処理物と一致する*8。 また融解熱はなたね油の吸収量を補正すれば，なたね油 を抽出した残りの処理物のそれとよく一致する（Table 1)。さらに，高分子鎖のーリックス配置の量に関係する 波数 $997 \mathrm{~cm}^{-1}$ の吸光度はなたね油のフィルムへの吸収 にははとんど影響されず, $A 997 \mathrm{~cm}^{-1} / A_{973 \mathrm{~cm}^{-1}}$ は油吸収の 補正を必要としない*4。これにはなたね油が970〜1000 $\mathrm{cm}^{-1}$ の波数域ではするどく, 強い吸収をもたないこと も幸いしている。上述の実験事実はなたね油が無定形領 域仅叹され結晶領域とほとんど熱力学的相互作用をも たないことを示す。熱処理工程における熱媒体の役割は たんに伝熱効率を高めるだけではないことは注目すべき 


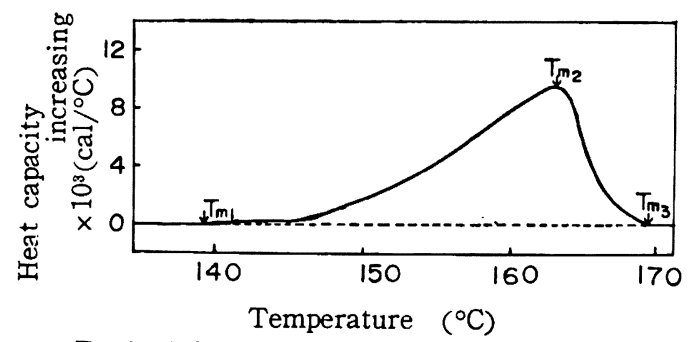

$T_{m 1}$ is defined as the temperature at which DSC curve begins to deviate from the base line. Strictly speaking, $T_{m 1}$ differs from the temperature of onset of melting.

$T_{m 2}$ is defined as the temperature at which melting velocity reaches maximum.

$T_{m 3}$ is the temperature at which the trace of crystallite melts.

Fig. 4-a. Representative DSC thermogram for quenched or annealed film which is obtained by heat-treatment at temperature below $70^{\circ} \mathrm{C}$ or above $150^{\circ} \mathrm{C}$.

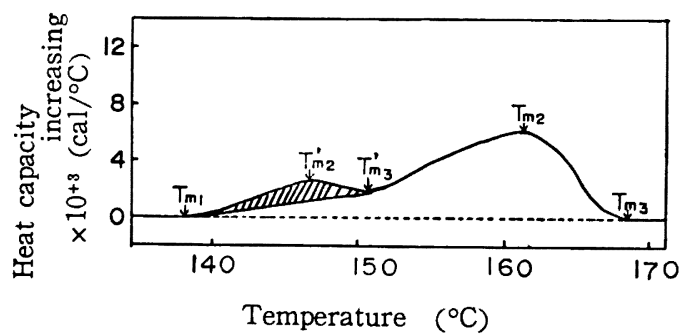

Lower melting shoulder or peak appeared in DSC diagram for film heat-treated in the narrow range of temperature. The distinction between two peaks is often not very apparent.

Fig. 4-b. Representative DSC diagram for film heat-treated in the temperature range 120 $\sim 150^{\circ} \mathrm{C}$.

である。

\section{3 熱解析}

Perkin-Elmer 社製 Differential Scanning Calorimeter DSC-1 型を用いた。温度は安息香酸（融点, $121.7^{\circ} \mathrm{C}$ ) および鉛（融点, $327.4^{\circ} \mathrm{C}$ ) の融点で較正し た。なお，安息香酸の融解熱量の実測値と文献値 (33.9 $\mathrm{cal} / \mathrm{g}$ ）とが 1 3\% 以内で一致したから融解熱量につい ての較正は不必要であった。

DSC を用いて得られるポリブロピレン（未処理物, $60^{\circ} \mathrm{C}$ 以下または $155^{\circ} \mathrm{C}$ 以上の熱処理物)の結晶融解曲 線 (DSC 曲線) の代表例を Fig. 4-a に示す。Fig. 4-a より, 見かけの融解開始温度 $T_{m 1}$, 融解速度が最大とな
る温度（単位温度幅あたりの結晶融解量が最大となる温 度） $T_{m 2}$, 見かけの融解終了温度 $T_{m b}$ が决定できる。融 解熱量 $\Delta H_{m}$ は区㓙のピーク部分の面積から求まる。

高分子物の DSC 測定に際して，試料が加熱されるた め, 熱測定の過程で再結晶化が進行したり, 部分融解を 伴ら再結晶化が起こったりして, 試料のるつ微細構造を

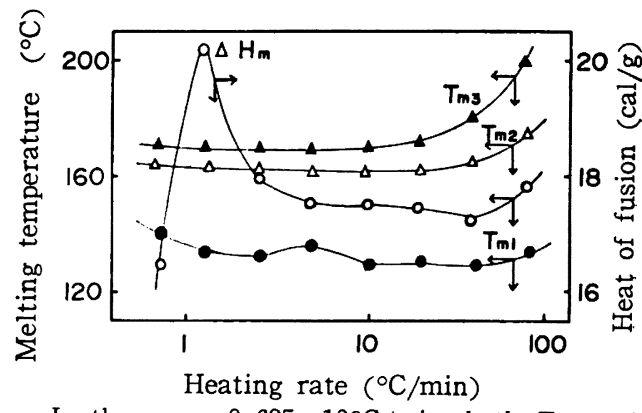

In the range $0.625 \sim 10^{\circ} \mathrm{C} / \mathrm{min}$, both $T_{m 2}$ and $T_{m 3}$ decreased with increase of the heating rate owing to the innegligible effect of structual change before melting.

In the heating rate larger than $10^{\circ} \mathrm{C} / \mathrm{min}$, $T_{m 2}$ and $T_{m 3}$ increased with increasing the heating rate due to the thermal lag.

Fig. 5-a. Effect of heating rate on melting points and heat of fusion for the quenched film of whole polymer.

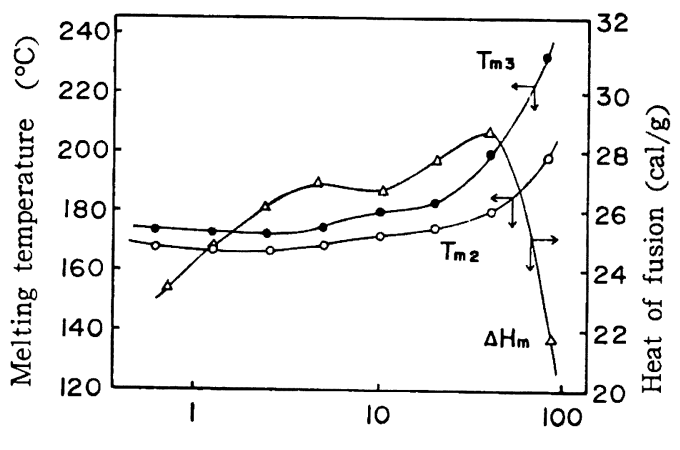

Heating rate $\left({ }^{\circ} \mathrm{C} / \mathrm{min}\right)$

It is suggested that the thermal lag can, strictly speaking, not be neglected even in the range of heating rate $5 \sim 10^{\circ} \mathrm{C} / \mathrm{min}$. Taking into account of structual change in quenched sample (ref. Fig. 5-a.), the heating rate $3 \sim 5$ ${ }^{\circ} \mathrm{C} / \mathrm{min}$ should be recommended.

Fig. 5-b. Effect of heating rate on melting points and heat of fusion for annealed whole polymer obtained by $163^{\circ} \mathrm{C}$ descending temperature method in rape seed oil. 
Table 2. Comparison of $T_{m 1} \sim T_{m 3}$ obtained from DSC thermogram with those from DAT thermogram for whole polymer $\left(\overline{M_{v}}=3.2 \times 10^{5}\right)$.

\begin{tabular}{|c|c|c|c|c|c|c|}
\hline \multirow{2}{*}{$\begin{array}{l}\text { Conditions of heat } \\
\text { treatment }\end{array}$} & \multicolumn{3}{|c|}{$\mathrm{DSC}^{\mathrm{D})}$} & \multicolumn{3}{|c|}{$\mathrm{DTA}^{\mathrm{bl}}$} \\
\hline & $T_{m 1}\left({ }^{\circ} \mathrm{C}\right)$ & $T_{m 2}\left({ }^{\circ} \mathrm{C}\right)$ & $T_{m 3}\left({ }^{\circ} \mathrm{C}\right)$ & $T_{m 1}\left({ }^{\circ} \mathrm{C}\right)$ & $T_{m 2}\left({ }^{\circ} \mathrm{C}\right)$ & $T_{m 3}\left({ }^{\circ} \mathrm{C}\right)$ \\
\hline Original (quenched) & 133 & 164 & 171 & 120 & 167 & 178 \\
\hline $60^{\circ} \mathrm{C}, \mathrm{D}^{\circ}$, , oil & 129 & 163 & 171 & - & 170 & 198 \\
\hline $100^{\circ} \mathrm{C}, \mathrm{D}^{\mathrm{a})}$, oil & 122 & 162 & 169 & 127 & 169 & 183 \\
\hline $140^{\circ} \mathrm{C}, \mathrm{D}^{\mathrm{a})}$, oil & 133 & 163 & 169 & 115 & 168 & 178 \\
\hline $\begin{array}{r}163^{\circ} \mathrm{C}, \mathrm{D}^{\mathrm{a})} \text {, nitrogen } \\
\text { atmosphere }\end{array}$ & 133 & 170 & 177 & - & 180 & 210 \\
\hline
\end{tabular}

a) Descending temperature method.

b) Conditions for measurements by DTA (DSC) are as follows; weight of sample; $25 \mathrm{mg}$ (10 $\mathrm{mg}$ ), heating rate; $10^{\circ} \mathrm{C} / \mathrm{min}\left(5^{\circ} \mathrm{C} / \mathrm{min}\right)$ reference material; fused silica (nothing), atmosphere; air (nitrogen gas) instrument; Shimazu DT-10 B (Perkin-Elmer DSC-1)

そのままとらえにくい，すなわち，微細構造を融解する 直前まで変化させずに維持しにくい。特に，ポリブロピ レンの急冷試料は $120^{\circ} \mathrm{C}$ 以下の温度域において, ス八 チカ晶から単斜晶へ結晶形が転移したり, 加熱状態でる 再結晶化するから ${ }^{2)}$, 熱測定過程で熱処理を著しく受け るであろ5。測定過程における試料の結晶融解前の構造 変化をなるべく小さくするためには，昇温速度をできる たけ大きくすればよい。しかし，昇温速度が大きいと，測 温しているふんい気温度と試料温度との間に差が生し て, $T_{m 1} \sim T_{m 3}$ が見かけ上高温側にずれる。実際の操作 条件は, 測定過程に拈ける試料の微細構造変化と熱的な 荤れの二つの因子の効果が全体として最小になるよらに 決定すべきである。急冷試料と熱処理 $\left(163^{\circ} \mathrm{C}\right.$ 降温法)試 料(いずれも未分別物)の融点と融解熱の昇温速度依存性 を Fig. 5-a, Fig. 5-b に示す。 $T_{m 1} \sim T_{m 3}$ が最小値を もつ昇温速度は $3 \sim 5^{\circ} \mathrm{C} / \mathrm{min}$ である。この昇温速度域 ては $\Delta H_{m}$ もほぼ一定である。したがって, 最適昇温速 度として 3 $5^{\circ} \mathrm{C} / \mathrm{min}$ が得られる。本論文では, 以下 述へる実験において, $5^{\circ} \mathrm{C} / \mathrm{min}$ を標準条件とした。た たし，この昇温速度を採用しても，急冷物は低温結晶化 と結晶転移を熱測定過程で伴らから, 少なくとも $120^{\circ} \mathrm{C}$ 以上の熱処理物以外の微細構造は, DSC 解析からは評 価でないことを強調したい。

つぎに, DSC 曲線から決定される $\mathrm{T}_{m 1} \sim \mathrm{T}_{m 3}$ と, 試 料の融点との関連性について, 三三検討してみた。 $\mathrm{Ke}^{181}$ は示差熱 (DTA) 曲線のピーク温度（便ぎ的に DTA 曲線です $T_{m 1} \sim T_{m 3}$ と表示することにする。Table 2 参照） $T_{m 2}$ を融点と定義した。たたし，ポリブロピレ ンでは融点はピーク温度よりも高温になると述べてい

*5 島津示差熱分析装置 DT - 10 B 型, 測定条件の詳 紐は Table 2 参照。
る。そこで, DT A 曲線のピーク温度が DSC 曲線の $T_{m}$ $\sim T_{m 3}$ のどれに対応するかを調べるために, 同一試料を 同時に DSC とDTA*5 で解析した (Table 2)。この結 果, ポリプロピレンフィルムの DTA曲線のピーク温度 $\left(T_{m 2}\right)$ は DSC 曲線の $T_{m 3}$ にほぼ対応することが確かめ られた。

次いで, DSC 曲線の $T_{m 3}$ または DT A 曲線の $T_{m 2}$ (䇺 密には, DSC 曲線の $T_{m 3}$ が DTA の $T_{m 2}$ よりも約 $1{ }^{\circ} \mathrm{C}$ 高い）とディラトメトリーの融点を比較することによっ て試料の見かけの融点に一致するかどらかを調べた。そ のために,

1）分別区分の無配向フィルムをディラトメータ一内 で $230^{\circ} \mathrm{C}$ で融解 $30 \mathrm{~min}$ 静置後 $140^{\circ} \mathrm{C}$ で等温結晶化さ せた。一次結晶化が完結してから $25^{\circ} \mathrm{C}$ の水中にディラ トメーター（試料部）を投入し冷却した。ついで， 0.2 ${ }^{\circ} \mathrm{C} / \mathrm{min}$ の昇温速度で加熱し, 比容一温度関係を求め た。融液相の比容-温度関係は直線で近似できるから、こ の直線で近似できるようになる温度をディラトメトリー の融点と定義した。このよ5にして定義された融点は, いわゆる比容温度曲線の折れ点よりも $1^{\circ} \mathrm{C}$ 前後高温に ずれた。

2）分別物を窒素ガスふんい気下で $230^{\circ} \mathrm{C} て ゙ 3 \mathrm{~min}$ 融解し, ついで $140^{\circ} \mathrm{C}$ に維持して球晶が互いに接触し あうまで結晶化させた。結晶化終了後急冷し，DSC 測 定（昇温速度, $5^{\circ} \mathrm{C} / \mathrm{min}$ ) を行なって $T_{m 1} \sim T_{m 3}$ を決 定した。

Fig. 6 には $T_{m 3}$ (DSC) と $T_{m}$ (dilatometry)を同時 に分子量に対してブロットしてある。この場合に利用し た武料が $140^{\circ} \mathrm{C}$-結晶化物なので, 熱測定過程における 熱処理効果が無視できるため, $T_{m 3}(\mathrm{DSC}) \simeq T_{m}$ (dilatometry）となった。もし，急冷試料をそのまま融点測定 に利用すると, $T_{m}$ (dilatometry) は $140^{\circ} \mathrm{C}$-熟処理物よ 


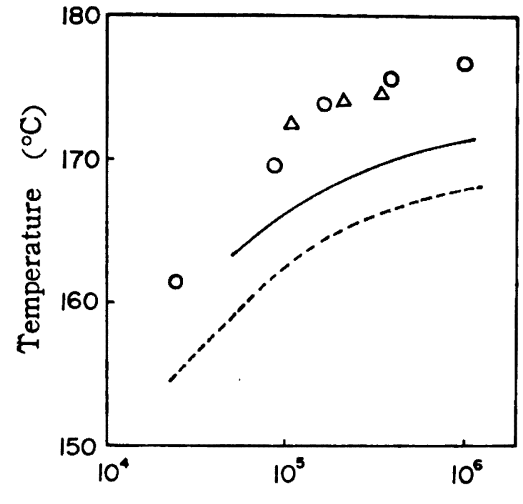

Molecular weight

O: $T_{m 3}$ from DSC measurement for wellcrystallized film, $\Delta:$ Melting temperature from dilatometry (heating rate: $0.2^{\circ} \mathrm{C} / \mathrm{min}$ ) for well-crystallized film, -: $T_{m s}$ curve from DSC measurement for quenched film, ‥: $T_{m 2}$ curve from DSC measurement for well-crystallized film.

$T_{m 3}$ from DSC analysis is in good agreement with the melting point for well-crystallized film for which the change in fine structure before melting can be neglected.

Fig. 6. Melting temperature from dilatometric measurement and $T_{m 3}$ from DSC analysis on fractions which are isothermally crystallized at $140^{\circ} \mathrm{C}$.

り約 $0.5^{\circ} \mathrm{C}$ 高温にずれ，一方, $T_{m s}$ (DSC) は $5 \sim 6^{\circ} \mathrm{C}$ 低温にずれる。したがって, $T_{m s}$ (DSC)< $T_{m}$ (dilatometry）となる。ディラトメトリーにおいて, 試料（充て ん剂としての水銀も含めて）の熱容量か大きく（試料量 （水銀を除いて）かi DSC の約 300 倍), 昇温速度を DSC のよらに大きくできない。そのため，熱測定過程におけ る試料の熱処理効果が常に DSC 測定の場合よりる大き い。これが急冷試料の $T_{m 3}$ (DSC) と $T_{m}$ (dilatometry) が一致しない原因である。

$140^{\circ} \mathrm{C}$-熱処理物の $T_{m 2}$ (DSC) は $T_{m}$ (dilatometry) よりも約 $10^{\circ} \mathrm{C}$ 低温にずれる。

\section{3. 結果と考察}

\section{1 融解温度}

\subsection{1 昇, 降温法熱処理物 (未分別物)}

$60^{\circ} \mathrm{C}$ 以下の熱処理では, $T_{m 1}$ は処理温度に影響され ないで約 $125^{\circ} \mathrm{C}$ であるが, $70^{\circ} \mathrm{C}$ で熱処理すると $T_{m 1}$ は いったん $60^{\circ} \mathrm{C}$ 付近にまで低下し，処理温度を上げるに つれて上昇した (Fig. 7-a)。

なお，Fig. 7-a のような関係は試料の分子量，分子

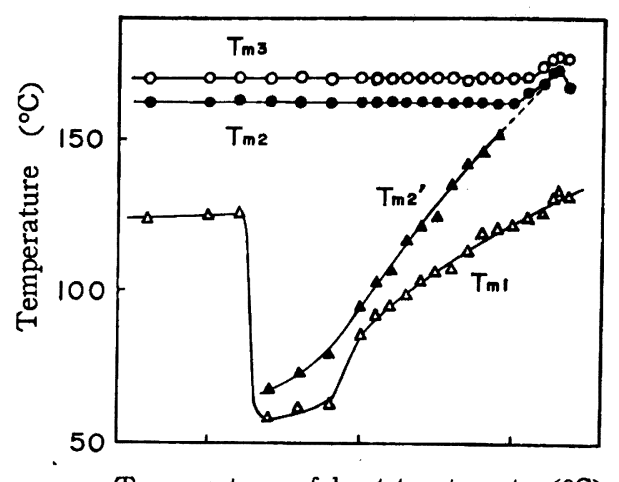

Temperature of heat-treatment $\left({ }^{\circ} \mathrm{C}\right)$ Apparent decrease in $T_{m 1}$ with annealing temperature above $70^{\circ} \mathrm{C}$ may be due to the small peak which appears as the result of annealing in this temperature range (c.f. Fig. 4b.).

The extrapolated value of $T_{m 2}{ }^{\prime}$ above $150^{\circ} \mathrm{C}$ coincides with the value of $T_{m 2}$.

Fig. 7-a. Plots of $T_{m 1}, T_{m 2}, T_{m 3}$ and $T_{m 2}$ against the temperature of heat-treatment by descending temperature method in a nitrogen atmosphere for whole polymer.

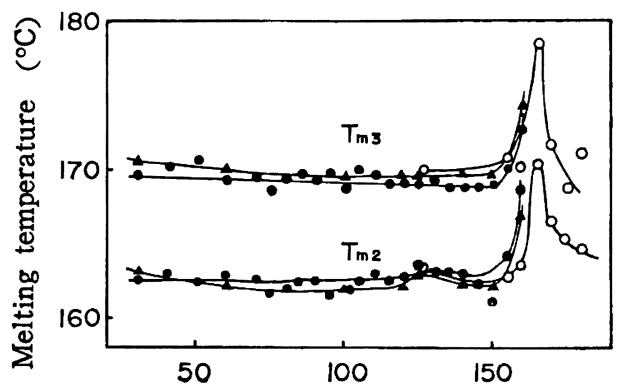

Temperature of heat-treatment $\left({ }^{\circ} \mathrm{C}\right)$

-: Ascending temperature method in rapeseed oil.

$\Delta$ : Descending temperature method in rapeseed oil.

$\Delta$ : Descending temperature method in a nitrogen atomosphere.

Fig. 7-b. Variation of melting temperature with temperature of heat-treatment for whole polymer.

量分布や熱処理方法には全く影筤されないで，ポリブロ ピレン無配向フィルムについて一般的に成立した。これ に対し $150^{\circ} \mathrm{C}$ 以下で処理された未分別物の熱処理物の $T_{m 2} \sim T_{m 8}$ は，処理温度にはとんど影響されない（Fig. 7-a, Fig. 7-b)。すなわち, $150^{\circ} \mathrm{C}$ 以下の熱処理によっ ては陚料の融点は上昇しない。 $150^{\circ} \mathrm{C}$ 以上の処理物の 


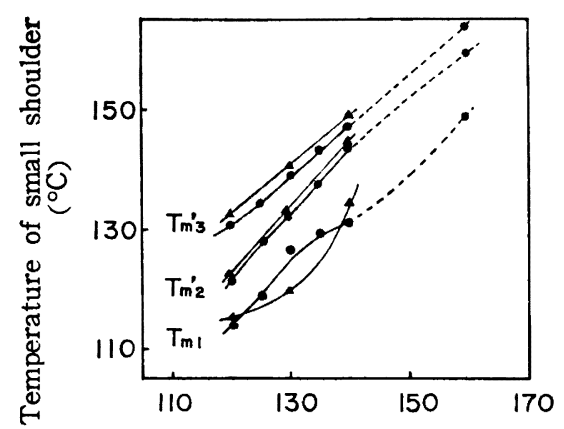

Temperature of heat-treatment $\left({ }^{\circ} \mathrm{C}\right)$ $T_{m 1}, T_{m 2}{ }^{\prime}$ and $T_{m 3}{ }^{\prime}$ are defined in Fig. 4-b. - Ascending temperature method in oil. $\Delta$ : Descending temperature method in oil. $T_{m 1}, T_{m 2}$ and $T_{m 3}$ linearly increased with temperature of heat-treatment. $T_{m 2}^{\prime}$ is, in general, a few degree higher than the temperature of heat-treatment. This kind of shoulder appeared again for samples annealed at $160^{\circ} \mathrm{C}$ by ascending temperature method.

Fig. 8. Change in small shoulder in DSC curve with temperature of heat-treatment.

$T_{m 2}, T_{m 3}$ は, $150^{\circ} \mathrm{C}$ 以下の処理物のそれより上昇し, 窒素ガスふんい気の降温法では $165^{\circ} \mathrm{C}$ で極大を示す。 熱処理方法, 熱媒体の違いは, 熱処理物の融点に影響し ない。なお, 昇, 降温法熱処理によって得られる処理物 の最高融点は, その試料がとりらる最高融点ではなく, 前 者は数 ${ }^{\circ} \mathrm{C}$ 低い。後者の融点は, 融点近傍において長時 間等温的に熱処理することによって達成できる（3.1.2 参照)。

分別物，未分別物を問わず，広い分子量範囲にわたっ て, $70^{\circ} \mathrm{C}$ 以上 $150^{\circ} \mathrm{C}$ 以下で熱処理された試料の DSC 曲線は, 低温側に小さな肩（またはピーク）をもつ。そ の代表例を Fig. 4-b に示す:この低温ピークは熱処理 方式をかえても常に認められた。低温ピークを Fig. 4-b のように $T_{m 2}, T_{m 3}{ }^{\prime}$ で規定すると, $T_{m 1}, T_{m 2}{ }^{\prime}, T_{m 3}{ }^{\prime}$ は 処理温度とともにほぼ直線的に增加する（Fig. 7-a, Fig. 8)。 $T_{m 2}{ }^{\prime}$ (低温ピーク温度) は熱処理温度より2, $3^{\circ} \mathrm{C}$ 高温にずれ, 高温側への外㨀線は $T_{m 2}$ の処理温度

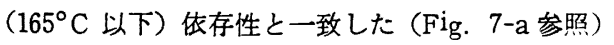

昇, 降温熱処理物ともに, $150^{\circ} \mathrm{C}$ 以上で熱処理される と, 低温ピークはいっけん消失し, 主ピークに重なっ た。しかし， $160^{\circ} \mathrm{C}$-熱処理物（昇温法）のDSC 曲線で は，再び低温ビークが分離した $\left(T_{m 2}{ }^{\prime}=162^{\circ} \mathrm{C}, T_{m 2}=\right.$ $170^{\circ} \mathrm{C}$ )*6 (Fig. 9)。この場合, 低温ビークの位置は 70

*6この現象は著者らとは独立に吉本 ${ }^{191}$ によっても最 近見出された。

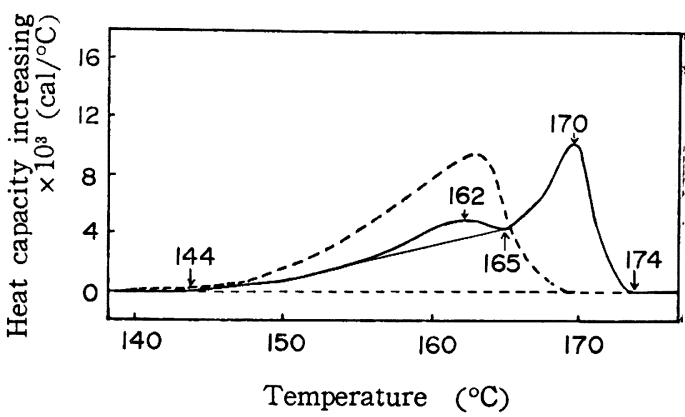

That small shoulder is separated from the main peak of melting means the existence of significant difference between small and main peaks even if the separation of two peaks are impossible for samples annealed at temperature above $150^{\circ} \mathrm{C}$.

DSC diagram for $150^{\circ} \mathrm{C}$-treatment is shown as dotted line for comparison.

Fig. 9. DSC diagram for whole polymer thermally treated by ascending temperature method up to $160^{\circ} \mathrm{C}$ in oil.

$\sim 150^{\circ} \mathrm{C}$ 熱処理物の低温ピークの処理温度 $160^{\circ} \mathrm{C}$ への 外㨀値とよく一致した。したがって, $150^{\circ} \mathrm{C}$ 以上の処理 物でいっけん消失した低温ピークは，たんに主ピークと 重なり合ったために分離できないだけで，低温ピークの 原因となる微細構造は $70^{\circ} \mathrm{C}$ 以上の熱処理によって常に 発生し, 主融解ピークを生ずる微細構造とは異なるもの であろら。低温融解ピークの全融解域において占める割 合は, 一般に数％であって (Table 3), 驇処理によっ て生成した結晶領域の大部分は主融解ピークに対応す る。

$160^{\circ} \mathrm{C}$ 以上で降温法熱処理した未分別試料の DSC 曲 線の数例を Fig. 10 に示す。 $163 \sim 165^{\circ} \mathrm{C}$ 熱処理物が最 も熱的に棈造が安定な結晶組織をもつ。

急冷試料をこの程度の温度 $\left(163 \sim 165^{\circ} \mathrm{C}\right)$ に加熱す ると, 試料の結晶（加熱過程で生成した結晶をも含め て）のほぼ $15 \%$ が融解せずに残る。この試料を室温ま で冷却し, さらに $163 \sim 165^{\circ} \mathrm{C}$ に加熱してももはや全結 晶の $65 \%$ 以上は融解しない。

$163 \sim 165^{\circ} \mathrm{C}$ 熱処理においては, むしろ一種の種つけ 結晶化 (Seeded Crystallization) が起こり, 熱的に安定 な末融解結晶が結晶化の核として作用し, それが冷却過 程で成長するのであろら。ポリプロピレンでは, 一般に 内部ひずみが除去される温度は $120 \sim 130^{\circ} \mathrm{C}$ とみなされ てきだ。この温度筑囲は結晶融解開始温度に対応する。 しかし、構造の熱的安定性の向上は $160^{\circ} \mathrm{C}$ 以上で処 理 しなければ期待できない。 $170^{\circ} \mathrm{C} て ゙$ 熱処理すると, ほと んど (95\%以上)の結晶が部分融解するためかえって結 
Table 3. Shadowed portion of small peak or shoulder in DSC diagrams (c.f. Fig. 4-b).

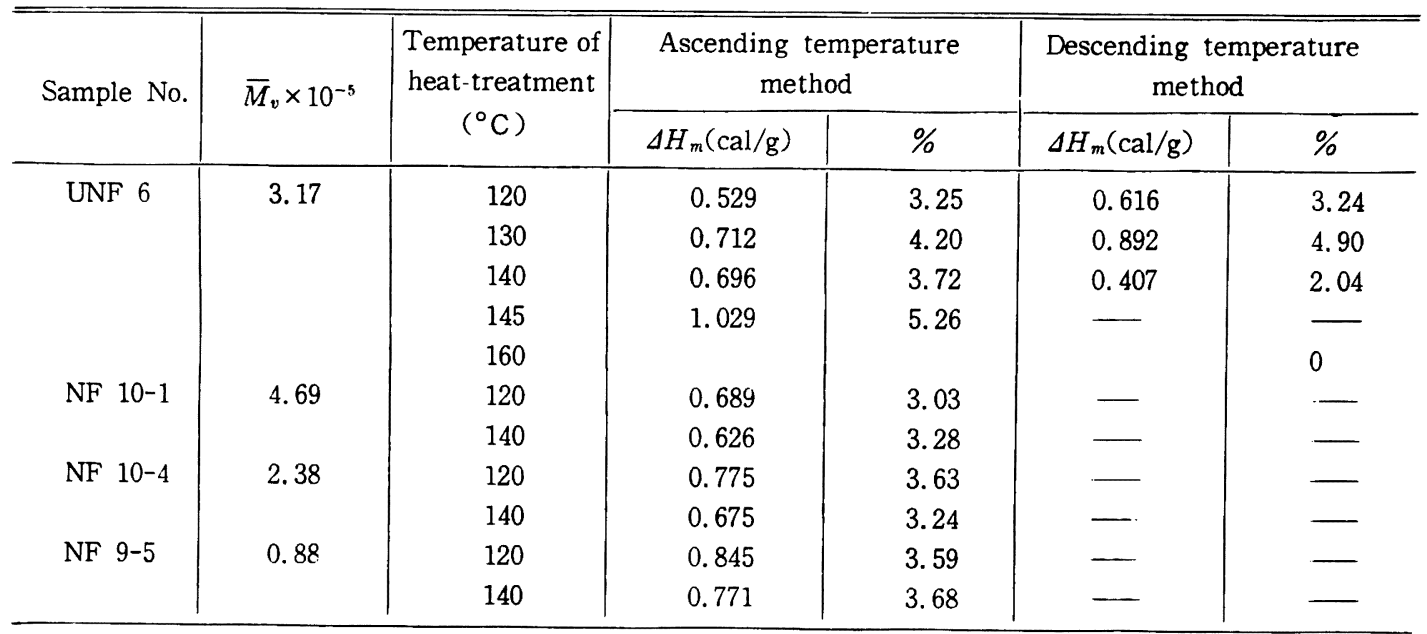

* Viscosity average molecular weight, $\bar{M}_{v}$ are calculated from intrinsic viscosity in decalin solution at $135^{\circ} \mathrm{C}$ using Kinsinger-Hughes' equation ${ }^{10)}$;

$[\eta]=1.10 \times 10^{-4} \bar{M}_{w}^{0.80}$

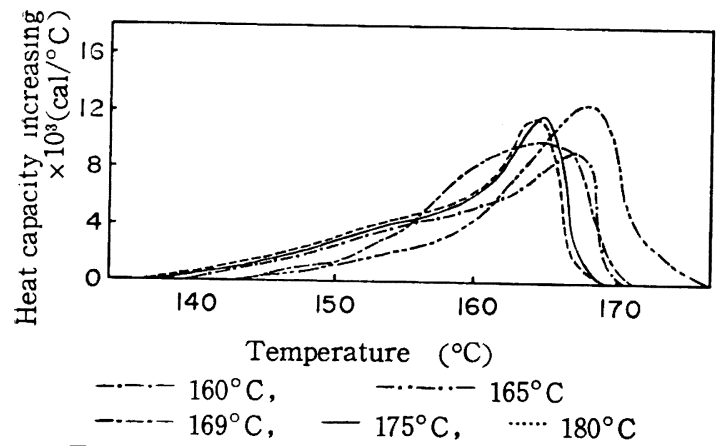

Fig. 10. Effect of temperature of heat-treatment (descending temperature method in a nitrogen atmosphere) in range 160 180 ${ }^{\circ} \mathrm{C}$ on DSC diagram for whole polymer.

晶化が進行せず，得られる熱処理物の熱安定性も低い $\left(150^{\circ} \mathrm{C}\right.$ 以下の熱処物のそれと同程度)。たたし，170〜 $180^{\circ} \mathrm{C}$ 熱処理物もフィルム状をそのまま保持している が, フィルム表面には（部分）融解を示寸凸凹が多い。

\section{1 .2 等温熱処理物（主として未分別物）}

等温熱処理物の融解挙動は昇, 降温法熱処理物のそれ とほとんど大差なく、 $T_{m 2}, T_{m 3}$ は処理温度 $150^{\circ} \mathrm{C}$ 以下 では変化せず, 低温融解ピークが 70 $150^{\circ} \mathrm{C}$ 熱処理物に 発生する。Fig. 11 K $120 \sim 160^{\circ} \mathrm{C}$ 等温熱処理物（未分 別物）の DSC 曲線を示す。Fig. 11 で実線は $2 \mathrm{hr}$ 処理， 点線は $9.5 \mathrm{hr}$ 処理の例である。 $150^{\circ} \mathrm{C}$ 以上で熱処理す る場合，処理時間が長くなると， $T_{m 2}, T_{m 3}$ が高温にず れる。特に, 昇、降温熱処理法によって最高融点が得ら

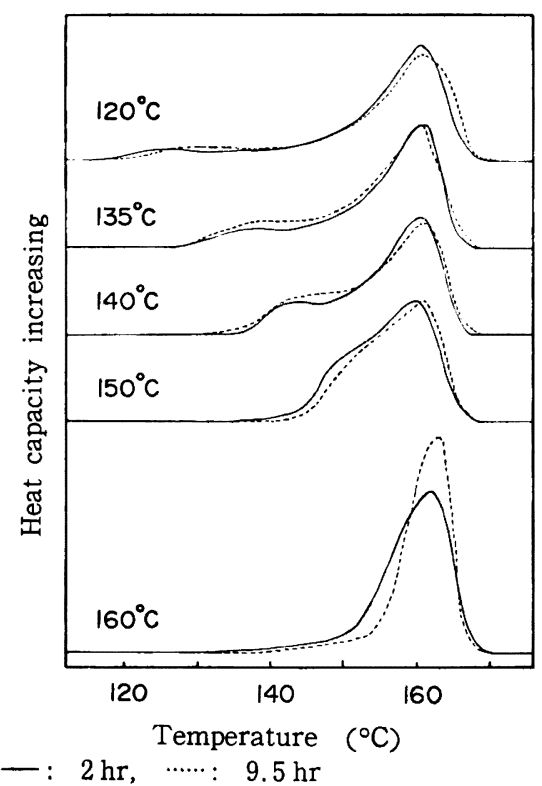

Fig. 11. DSC diagrams for films of whole polymer isothermally heat-treated at indicated temperature in nitrogen atmosphere.

れる処理温度で等温熱処理すると, $T_{m 2}, T_{m 3}$ はともに 処理時間とともに高温にずれ，ほぼ $100 \mathrm{~min} て ゙$ 平衡値に 達する (Fig. 12)。 $140^{\circ} \mathrm{C}$ 熱処理では, 2 $570 \mathrm{~min} の$ 処理時間範囲で $T_{m 1}, T_{m 2}, T_{m 3}$ はほとんど一定である 


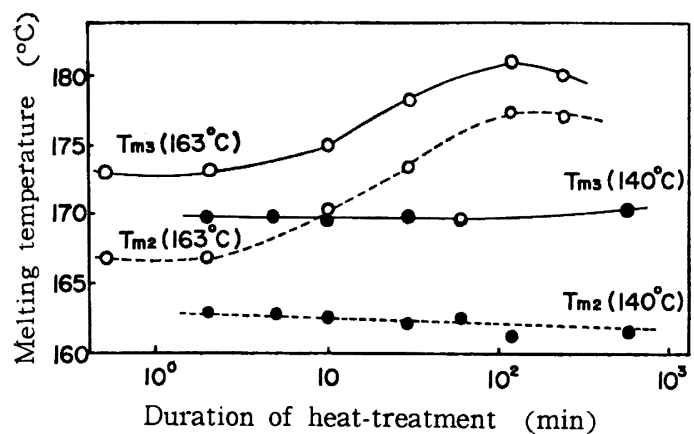

Fig. 12. Change in melting temperature for fraction $\left(\bar{M}_{v}=3.7 \times 10^{5}\right)$ with duration of heat-treatment at constant temperature indicated in parentheses in Figure.

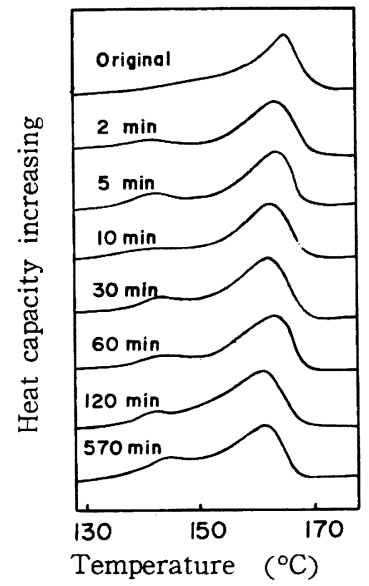

Heat-treatment was carried out in oil thermosetting at $140^{\circ} \mathrm{C}$. Small peak charastaristic of $140^{\circ} \mathrm{C}$ treatment appears in sample heat-treated for $2 \mathrm{~min}$. Temperature of small peak, $T_{m}{ }_{2}$ slightly increased with duration of heat-treatment.

Fig. 13. Effect of duration of isothermal heattreatment at $140^{\circ} \mathrm{C}$ for whole polymer.

(Fig. 13)。

$140^{\circ} \mathrm{C}$ 熱処理物（未分別物）の DSC 曲線に及ぽす 処 理時間の効果を調べると (Fig. 13)，2 min 間の熱処理 によって, 低温融解ピークが発現した。この低温融解ピ 一ク $\left(T_{m 2}{ }^{\prime}\right)$ は, 処理時間涱くなるにつれて, 中户明 り上らになり，大きくなる。 $T_{m 2}{ }^{\prime}\left({ }^{\circ} \mathrm{C}\right)$ は長時間処理に よって数 ${ }^{\circ} \mathrm{C}$ 高温にずれ,

$$
T_{m 2}{ }^{\prime}=138+1.8 \log t \quad\left(1 \leq t \leq 10^{3}, t: \min \right)
$$

${ }^{* 7}$ 多重熱処理に括ける 2 段熱処理以降の熱処理飞打 ける処理時間の DSC 曲線に及注す奻果は無視でき ない 20)のに比べて対照的である。

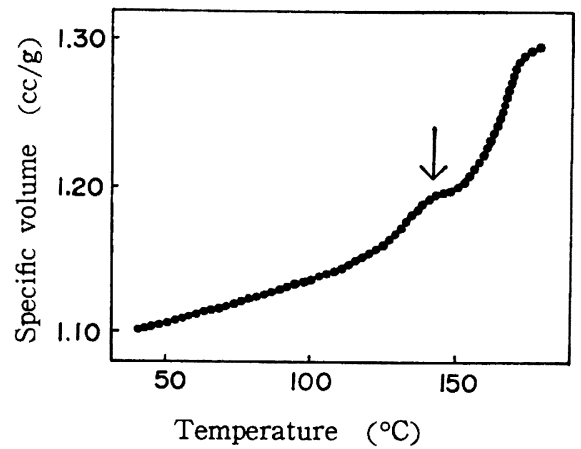

If polymer is annealed for very long time at constant temperature, abnormal and rapid decrease in volume expansion coefficient which is due to the thermal stability of crystallites is detected in the narrow range of the temperature (arrowed) which is a few degree higher than the temperature of previous heat treatment.

Fig. 14. Specific volume-temperature relationship for fraction $\left.\bar{M}_{v}=1.84 \times 10^{5}\right)$ which was thermally treated previously for 211 hr at $140^{\circ} \mathrm{C}$.

の実験式が成立する。ここで, $t$ は熱処理時間 (min) である。これより, 熱処理によって起こる微細構造変化 のらち低温融解ピークの変化は短時間内で起こり．その 構造は主として処理温度（または最高处理温度）で決ま る*7。一方, 主融解ピークは, 処理温度が低ければ観测 時間内では変化しないか，処理温度を高くするとかなり 経時的に変化することが確かめられた。

たとえ $T_{m 2}, T_{m 3}$ は高温にずれなくても，長時間の熱 処理によって, 熱処理温度付近で構造がかなり熱的に安 定化する。この 1 例を以下に示す。ほぼ完全に $\left(1 \times 10^{-4}\right.$ $\mathrm{mmHg}$ 以下に) 酸素を排除した窒素示んい気下に沶い て, 分別物 $\left(\bar{M}_{v}=1.84 \times 10^{5}\right)$ の急冷フィルムを $140^{\circ} \mathrm{C}$ で $211 \mathrm{hr}$ 加熱した。熱処理物の比容の温度変化を常法21 に従ってディラトメトリーから決定した（Fig．14）。熱 処理温度より数度高温 $\left(144^{\circ} \mathrm{C}\right)$ に打いて, 一時的な体 積膨張係数の低下が起こる。比容を結晶化度に換算する と, この温度域 $\left(144 \sim 150^{\circ} \mathrm{C}\right)$ では結晶化度が一定 値 を示して, 普通に見られるよらな, 具温に伴ら結晶化度 の低下は起こらない。この結果, $140^{\circ} \mathrm{C}$ 長時間熱処理に 伴って, $144 \sim 150^{\circ} \mathrm{C}$ 付近での熱安定性が良い結晶領域 が多くなるといえる。この温度域は低温ピークの融解領 域に対応している (Fig. 8 参照)。

\section{1 .3 分子量と分子量分布の効果}

分別物の降温法 (空素ガスふんい気) 熱処理物の DSC 曲線の例を Fig. 15 に示す。分別物も $70 \sim 150^{\circ} \mathrm{C}$ 熱好 


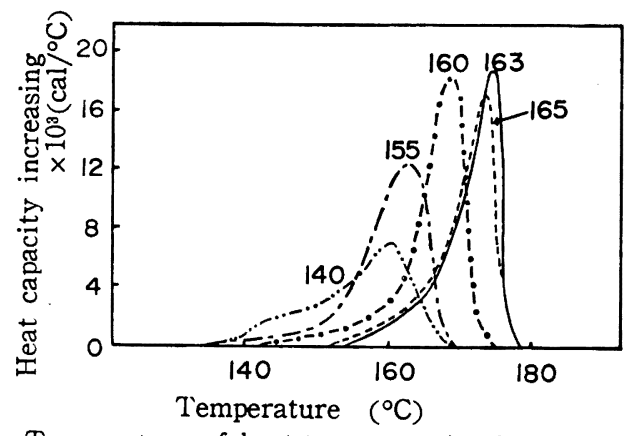

Temperature of heat-treatment is shown on curve.

Fig. 15. Representative DSC diagrams for fraction $\left(\bar{M}_{v}=4.69 \times 10^{5}\right)$ treated by descending temperature method in a nitrogen atmosphere.

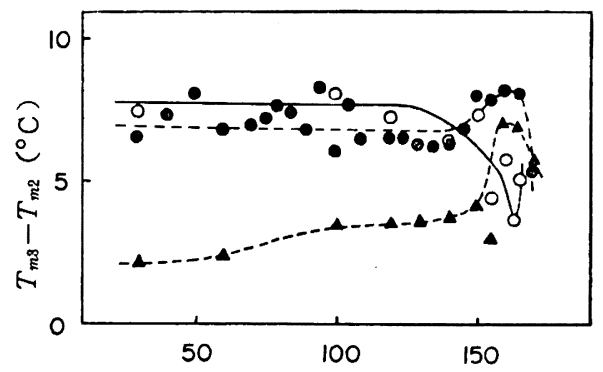

Temperature of heat-treatment $\left({ }^{\circ} \mathrm{C}\right)$

- : whole polymer $\left(\bar{M}_{v}=1.93 \times 10^{5}\right)$

A : whole polymer $\left(\overline{M_{v}}=3.95 \times 10^{3}\right)$

O: fraction $\left(\overline{M_{v}}=4.69 \times 10^{5}\right)$

Fig. 16. Plots of melting range $\left(T_{m 3}-T_{m 2}\right)$ against the temperature of heat-treatment for fraction and whole polymers.

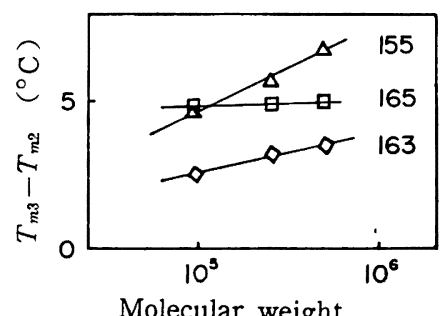

Samples which are annealed at $163^{\circ} \mathrm{C}$ give minimum value of $\left(T_{m 3}-T_{m_{2}}\right)$.

Temperature of heat-treatment (descending method in nitrogen atmosphere) is shown on the curve.

Fig. 17. Plots of melting range $\left(T_{m 3}-T_{m 2}\right)$ against molecular weight for fractions.

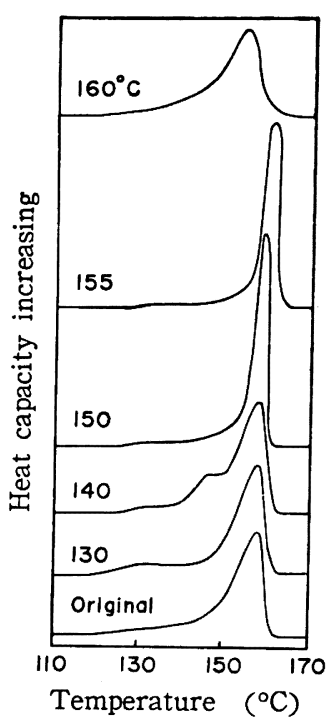

Temperature of heat-treatment is shown on the curve.

Fig. 18. DSC diagrams for isotactic unfraction of extremely low molecular weight $\left(\bar{M}_{v}=\right.$ $4.0 \times 10^{3}$ ) heat-treated by descending temp erature method in a nitrogen atmosphere.

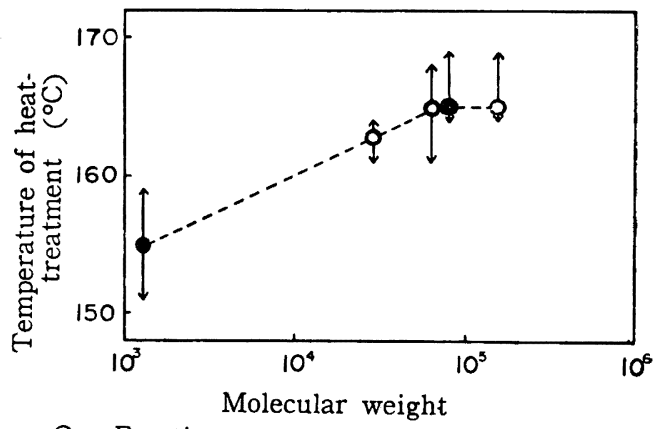

O: Fraction, $\quad$ : Whole polymer

Effect of molecular weight distribution on characteristic temperature is insignificant.

Fig. 19. Characteristic temperature of heattreatment which gives the maximum melting temperature $T_{m 8}$ as a function of molecular weight.

理によって低温融解ピークを発生する。同じ程度の分子 量で比較すると, $140^{\circ} \mathrm{C}$ 以上で熱処理された分別物の融 解ピークは, 未分別物のそれよりかなり鋭く, 融解温度 幅も狭い。融解温度幅の目安として $\left(T_{m 8}-T_{m s}\right)$ むとっ たのが Fig. 16 である。末分別物は $160 \sim 165^{\circ} \mathrm{C}$ で融 解温度幅が極大値をとる。これに反し, 分別物の融解温 度幅はこの温度域では狭くなる。この関係をさらに詳細 


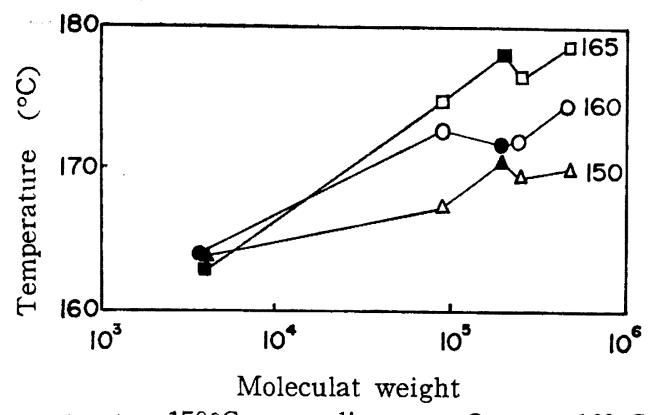

$\Delta, \Delta: 150^{\circ} \mathrm{C}$ annealing, $\mathrm{O}, \bullet: 160^{\circ} \mathrm{C}$ annealing, $\square, \square: 165^{\circ} \mathrm{C}$ annealing open mark: fractions closed mark: whole polymer

Fig. 20. Molecular weight dependence of $T_{m 3}$ for fractions and whole polymer.

に調ベると（Fig. 17）, 最高融点を与える温度で処 理さ れたフィルムの融解温度幅が著しく狭くなることがわか る。分子量の増加につれて融解温度幅もわずかに広くな る。

分子量が極端に低い $\left(\bar{M}_{v}=3.9 \times 10^{3}\right)$ イソタクチック 物の DSC 曲線を Fig. 18 にまとめてある。130〜 $150^{\circ} \mathrm{C}$ 熱処理によって，低温ピークが発現する。 $150 \sim 155^{\circ} \mathrm{C}$ 熱処理によって主融解ピークは高温にずれ, 融解温度幅 も狭くなる。たたし， $T_{m 3}-T_{m 2}$ で融解幅を表わすとあ まり明確ではなくなる(Fig. 16)。

最高融点を与える昇, 降温法熱処理温度（最適熱処理 温度）は, $\bar{M}_{v}=9 \times 10^{4} \sim 5 \times 10^{5}$ で $163 \sim 165^{\circ} \mathrm{C}$ であっ て, 分子量分布の影響はない(Fig. 19)。分子量が極端 に低くなると，最適処理温度は $150 \sim 155^{\circ} \mathrm{C}$ になる。熱 処理による融点の最大向上度は, $\bar{M}_{v}=9 \times 10^{4} \sim 5 \times 10^{5}$ で は $7 \sim 10^{\circ} \mathrm{C}, \bar{M}_{v}=4 \times 10^{3}$ に対しては $0.5 \sim 1.0^{\circ} \mathrm{C}$ であ る。

$T_{m 3}$ の分子量依存性を Fig. 20 に示す。熱処理温度 が高くなるにつれて $T_{m 3}$ の分子量依存性は著しくなる。

Fig. 19 で示された最高融点を与える温度で試料を処 理すると, その $T_{m 3}$ (最高融点) の分子量依存性は次式 $T_{m 8}\left({ }^{\circ} \mathrm{C}\right)=136.1+7.6 \log \bar{M}_{v}$

$\left(4 \times 10^{3} \leq \bar{M}_{v} \leq 5 \times 10^{5}\right)$

で表わされる。なお， $T_{m 2}$ も同様な分子量依存性をもつ。

3.2 DSC 曲線で見出される低温吸熱ピークの原因

\section{2 .1 現在までに提案されている説明}

3.1 で見出されたような低温吸熱ピークは，すでに

DT A 解析によっても多くの研究者(1),18),211 271 によって 報告されている。そこで, DSC 解析から明らかに低温 融解ピークをるつことが確かめられている試料を DTA

*8 スメチカ晶の融解は実際には起こらない。融解に 先立って転移が起こるからである2)。
解析した。しかし，DTA曲線は低温吸熱ピークを示さな かった。したがって, DSC 曲線の低温ピークは, DTA 曲線のそれと同一原因に基くとは速断できない。本論文 では, DTA曲線の低温ピークの原因として提案されて いる説明の妥当性をまず検討した。

Tolchinskii ら 211 は低温ピークを構造的な（おそらく は立体規則性度の)違いに原因させている。堀-飯田ら ${ }^{221}$ は未分別ポリブロピレンを沸とらアセトン，へブタンで 抽出し, その抽出残と抽出物の DTA曲線を解析し, 立 体規則性度の低い部分が混在すると低温ピークが発生す ると述べている。 $\mathrm{Ke}^{51,18)}$ によると, 1 度融液から抗酸 化剂なしで調製された試料は，2重吸熱ピーク（一つは 主ピーク, 一つは低温融解ピーク)をもつが, 融解前に 抗酸化剂を添加して打けば低温ピークが消失することか ら, 試料の DTA 曲線の 2 重ピークを試料の調製, 熱測 定過程で起こる酸化崩かいに関連づけている。田村一藤 代ら ${ }^{23)}$ は, 低温ピークが融液からの冷却速度 (0.3〜 $0.5^{\circ} \mathrm{C} / \mathrm{min}$ と $3 \sim 5^{\circ} \mathrm{C} / \mathrm{min}$ の 2 水準) の影響をわず か受け, 冷却速度を遅くすると, 小さい（低温融解）ピ ークは高温側の主ピークに近づくようにみえることか ら, 低温ピークは準安定パラクリスタルのスメチカ晶構 造の融解に原因し, 低温ピークの位置と高さはスメチカ 変態の分布と量に関係すると推論した。Schwenker ら ${ }^{24)}$ は, ポリフロピレン繊維の延伸糸の DTA 曲線は 2 重ピーク $\left(158^{\circ} \mathrm{C}, 174^{\circ} \mathrm{C}\right)$ を与えるが, 未延伸系で

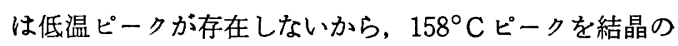
融解に先立つ無配向化に原因させた。DTA 曲線の 2 重 ピークを最も系統的に研究した尾山ー高見沢ら 251ー27) に よると, 低温ピーク $\left(125^{\circ} \mathrm{C} \sim 155^{\circ} \mathrm{C}\right)$ は $\beta$ 変態(後述) に基因する。 $\beta$ 変態が低温ピーク（140 $\mathrm{C} ）$ の原因とな りらることについては最近, 粟屋 ${ }^{281}$ によって示された。

3.2 .2 低立体規則性度部分の融解, スメチカ晶の転 移, 酸化

3.1 において見出だされた DSC 曲線の低温ピークは， 高度にイソタクチック無配向フィルムを少なくとも $70^{\circ} \mathrm{C}$ 以上まで熱処理することによって初めて発現する。 一方, スメチカ晶からなる急冷試料は, 熱測定過程に括 いて単斜晶に転移する。その転移温度域は $75 \sim 110^{\circ} \mathrm{C}$ である21。一方, 急冷試料の DSC 曲線は上記の転移温度 域では異常吸熱を示さない。したがって,スメチカ晶の 転移は熱の出入りを伴わないか，または検出できない程 度にわずかである。これに対し，完全に単斜晶系に転移 した試料 $\left(110^{\circ} \mathrm{C}\right.$ 以上の熱処理物)においても低温ピー クが顕著に見出される。結局低温ピークの温度域はスメ チカ晶の転移温度域と部分的には重なっているがてれと は明らかに異なる。

したがって, 低立体規則性度部分の融解, スメチカ晶 の単斜晶への転移, スメチカ晶の融解*8, 無配向化効果 


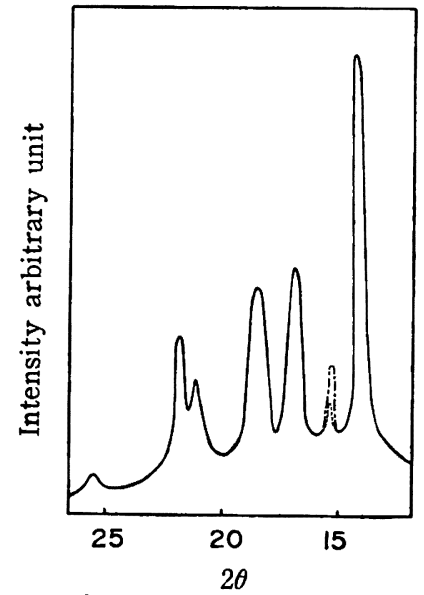

Content of $\beta$ form (\%) ........: 5, -.-..: 10

The indicated percentage means the weight fraction of $\beta$-form in total crystalline region. Coexistence of a few percent of $\beta$-form in $\alpha$-form should be detected by X-ray diffraction measurement.

Fig. 21. Calculated X-ray diffraction curves for polypropylene which is assumed to consist of two different kinds of crystalline forms; $\alpha$ (monoclinic) and $\beta$-forms.

などは低温ピークの原因ではない。

\section{$3.2 .3 \beta$ 変態の融解}

つぎに, 低温融解ピークが $\beta$ 変態の融解に原因する可 能性についてやや詳細に検討してみた。

$\beta$ 変態は最初 Keith-Padden'29!によって見出だされ た。彼らの表示法に従らと, 球晶のタイブIII*9 とタイプ $\mathrm{IV} * 10$ が $\beta$ 変態をとる ${ }^{30)}$ 。X線回折による $\beta$ 変態の構造 解析はその後 Jones ら ${ }^{31}$ によって行なわれた。その結 果, 市眅高分子物の融液を通常 $\alpha$ 変態（単斜晶をさす） を作る条件で泠却することによって得られた $\beta$ 型結晶に ついてのX線回折図が確定している。

$\beta$ 変態が低温ピークに対応するのならぱ，低温ピーク の占める割合 (Table 3 参照) から考えて, 少なくと も数％程度は単斜晶に混在しているはずである。一方, もし $\beta$ 変態が単斜晶に混在しているならば, 回折角 $\theta=8^{\circ}$ 付近に鋭い回折像が見出だされるはずである（文

*9 球晶の半径方向とその接線方向の屈折率の差（球 晶の複屈折度) は負。 $120^{\circ} \mathrm{C}$ 以下の温度で結晶化 させるとき生成する。特に溶融温度から急速に冷 却する塕合に発生しやすい。タイフ III は非常に まれに見出される。

*10 球晶の複屈折度が負。 $128 \sim 132^{\circ} \mathrm{C}$ で結晶化させ る場合, 大部分のタイプI の球晶に全く偶発的に 混って発生する。
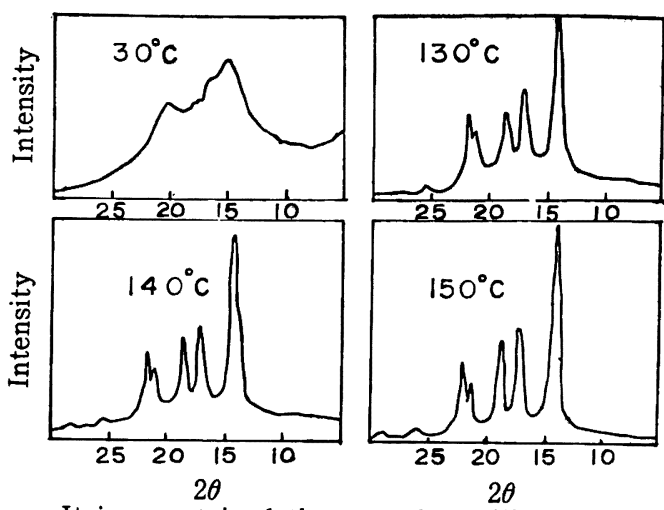

It is ascertained that samples utilized in this study may have not $\beta$-form.

Fig. 22. X-ray diffraction curves for whole polymer annealed by ascending temperature method in oil up to the indicated temperature.

献 30), Fig. 1 参照)。これを確かめるために, $\beta$ 変態 が単斜晶に混在している場合のX線回折図を合成した (Fig. 21)。この場合, Jones らの方法 ${ }^{31)}$ に従って, $\beta$ 変態の全結晶領域に対する含有率 $\kappa$ を, いくつかの結晶 面の回折強度の相対的な和に対する $\theta=8^{\circ}$ 弱に存在す る $(h k 0)$ 面反射強度の割合で定義した。すなわち,

$$
\kappa=\frac{H \beta_{1}}{H \beta_{1}+\left(H \alpha_{1}+H \alpha_{2}+H \alpha_{3}\right)}
$$

ここで, $\alpha_{1}$ は (110) 面, $\alpha_{2}$ は (040) 面, $\alpha_{3}$ は (130) 面反射を意味し， $\beta_{1}$ は上述の $\beta$ 変態の $(h k 0)$ 面反射で ある。Fig. 21 より, 数\%（括そらくは $2 \%$ 以上） $\beta$ 変 態が存在すれば，実験的に検出できるはずである。Fig. 22 に昇温法熱処理物 (未分別物) のX線回折図形の測 定例を示す。 $\beta$ 変態の存在は全く認められない。なお, 念のため透過 X線回析も行なったが， $\beta$ 変態は認められ なかった。

したがって, DSC 曲線の低温ピークは $\beta$ 変態の融解 のためではない。低温ピークのピーク温度が熱処理条件 に対応して広範囲 $\left(70 \sim 160^{\circ} \mathrm{C}\right)$ に変化することも $\beta$ 変 悲の融解説を否定する。

\section{2 .4 溶液結晶物の低温融解ピーク}

高分子単結晶の構造についての知見が融液からの結晶 化物の微細楧造を解明するための手がかりを与える。同 様に, 高分子単結晶の熱処理による構造変化が十分に解 明されるならば，熱処理を分子的基礎から説明できる見 込みがある。そこで, 低温融解ピークが融液からの結晶 化物だけに特徵的なものであるかどらかを確かめるた め, 溶液から生成された結晶の微細構造の熱処理による 変化を DSC 解析によって検討した。

$0.1 \% p$-キシレン溶液 $\left(76^{\circ} \mathrm{C}\right)$ から生成した結晶（析 


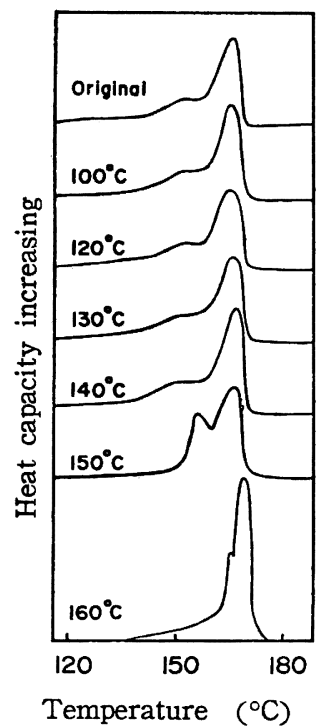

Solution grown crystals were crystallized from $0.1 \% p$-xylene solution by allowing to stand at $76^{\circ} \mathrm{C}$ for 20 or $50 \mathrm{hr}$. Original crystals have small peak at $153^{\circ} \mathrm{C}$ which can be interpreted as annealing effect in the mother solution. The small peak does not change for crystals which are heat-treated at temperature below $140^{\circ} \mathrm{C}$. The portion of small peak remarkably increases and its' peak temperature slightly increases for $150^{\circ} \mathrm{C}$ treatment.

Heat-treatment at $150 \sim 160^{\circ} \mathrm{C}$ gives small peak, temperature of which corresponds to temperature of heat-treatment.

Fig. 23. Influence of heat-treatment on DSC diagram for solution grown crystals (whole polymer).

出時間, $20 \mathrm{hr}$ と $50 \mathrm{hr}$, 析出温度で口過）を窒素ガス ふんい気の降温法で熱処理した。末処理物および熱処理 物の DSC 曲線を Fig. 23 亿示す。

溶液結晶はすでに $153^{\circ} \mathrm{C}$ に低温融解ピーク(またはか た）をつっこの $T_{m 2}{ }^{\prime}$ は $140^{\circ} \mathrm{C}$ までの熱処理によって 杜全く変化を受けない。たたし, $140^{\circ} \mathrm{C}$ 処理物は $140^{\circ} \mathrm{C}$ 付近から融解する部分の増加が認められた*11。 $150^{\circ} \mathrm{C}$ 熱処理によって低温ピークがより明りょうに分離される

*11この現象は, 多重熱処理物について一般的に起こ る $^{20)}$ 。

*12 最近, 高柳 ${ }^{32)}$ はp-キシレン溶液から析出させた ポリエチレン単結晶を DSC で解析し, 結晶析出 温度の上年につれて, 低温ピークが発生しこのピ 一ク温度は高温にずれることを見出している。
( $T_{m 2}{ }^{\prime}$ は変化しない)。 $160^{\circ} \mathrm{C}$ 熱処理物の $T_{m 2}{ }^{\prime}$ は $167^{\circ} \mathrm{C}$ にずれ，低温ピークは主ピークとほとんど重なった。溶 液結晶は析出後母溶, 液中で静置される間に熱処理効果 を受けて，低温融解ピークを生じたと解釈できる*12。 ポリプロピレンのキシレンへの溶解温度 $\left(115^{\circ} \mathrm{C}\right)$ と結 晶化温度の差は, ほほ $T_{m 3}-T_{m 2}{ }^{\prime}$ (約 $30^{\circ} \mathrm{C}$ ) に一致す るから, 過冷却度が低温ピーク温度を決定しているよう にみえる。

$150^{\circ} \mathrm{C}$ 以上の温度に拈ける熱処理によって初めて低温

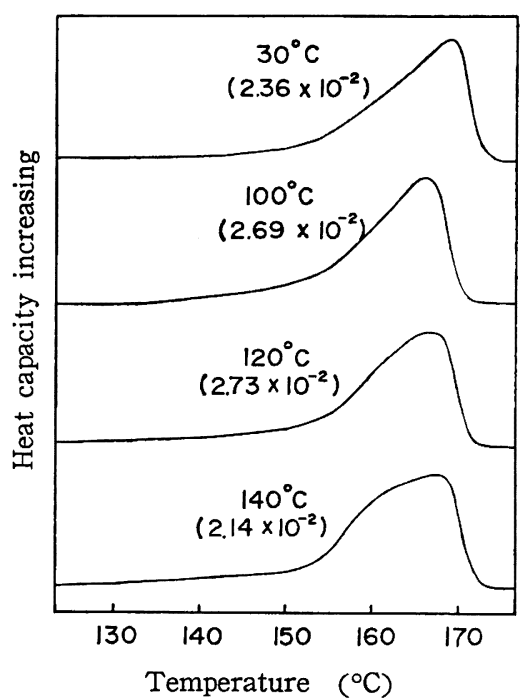

30 denier undrawn filaments of $\overline{M_{v}}=1.33 \times 10^{5}$ were melt spun from fraction using the following methods: Temperature of die, 290 ${ }^{\circ} \mathrm{C}$. ; the ratio of linear velocity of filament at winding roll to that at spinneret (draft ratio) 200; apparutus, plunger-type extruder specially designed in our laboratory (details should be refered to previous paper ${ }^{33)}$ ). Undrawn filaments were stretched up to stretch ratio of 4 at the indicated temperature with rate of $6 \mathrm{~cm} / \mathrm{min}$ in rape-seed oil which was completely removed by washing filaments with acetone and ethanol in the stretched state. Birefringence $\Delta n$ in filaments was determined by the retardation method and indicated in the diagram.

The fact that small peak appears only for filament stretched at $140^{\circ} \mathrm{C}$ strongly suggests that small peak melting at lower temperature is not due to the disorientation of crystallite immediately before melting.

Fig. 24. DSC diagram for the stretched polypropylene filament (ca. 8 denier). 
ピークが高温にずれる。そのときの $T_{m 2}{ }^{\prime}$ 值も処理温度 より数 ${ }^{\circ} \mathrm{C}$ 高温となる。このように, 比較的微細構造の 単純な溶液結晶も, 熱処理によって明確な低温融解ピー クを発生することから, 低温融解ピークはポリブロピレ ンの熱処理に伴う再結晶化現象に本質的なものであろ 5。

\subsection{5 結晶融解直前に起こる無配向化}

瀻維の融解直前に見られる（主として結晶の）無配向 化が DSC 曲線の低温融解ピークの原因となりらるか否 かをつぎに確かめた。

著者らによって試作された，ピストン押出式小型紡系 装置 ${ }^{33)}$ を利用し，分別物より Fig. 24 に示す条件にて 30 denier の未延伸系（瀻維の $\bar{M}_{v}=1.33 \times 10^{5}$ )を作った。 未延伸采は, 各々 $30^{\circ} \mathrm{C}, 100^{\circ} \mathrm{C}, 120^{\circ} \mathrm{C}, 140^{\circ} \mathrm{C}$ に保 ってある熱媒体中で 4 倍に延伸した。延伸系は緊張状態 で室温にまで邻却し, 付着熱媒体を洗浄除去してから自 由端にもどした。このよらにして得られた延伸系の DSC 曲線を Fig. 24 に示す。㵶維の複屈折度は延伸温 度によって系統的な变化をしない。したがって, 瀻維の 融解直前に無配向化が起こるにしても DSC 曲線の形に は影響しない。 $140^{\circ} \mathrm{C}$ 延伸系は低温融解部分が多くな るが、これは瀻維が延伸過程で就処理を受けたためであ ろら。なお，延伸過程で繊維は $4 \mathrm{~min}$ 間所定の温度に保 たれた。

\subsubsection{2 相結晶化}

結局, ポリブロピレンの低温融解ピークは熱処理操作 に伴って発生し, 部分融解とそれに引きつづいて起こる 再結晶化過程に打いて, 結晶采は全く同一(単斜晶) で あるが熱的安定性のみを巽にする 2 種類の結晶相が生成 されることが実験的に明らかになった。なお，二つの結 晶相の生成は, 分子量, 分子量分布, 熱処理方法 (加熱 形式，熱媒体）に関係なく, ポリプロピレンの熱処理に 特徵的な現象である。

なお，主融解ピークと低温ピークは以下に述べるよう な性質をるつ。

1）主ピークは融液からの結晶化温度, 時間に無関係 である*13。ポリエチレンでは等温結晶化物と急冷過程に おいて生成した結晶領域とが明らかに異なる融解ピーク を示す27,34)が，ポリプロピレンでは全く区別できない。

2）融液からの結晶化物そのまま（たいていの場合は 1 次結晶化物）では低温融解ピークをもたない。

3）低温融解ピークは, むしろ正確には熱処理温度に

${ }^{* 13}$ 分別物（5 種）を $120 \sim 150^{\circ} \mathrm{C} て ゙ ，$ 球晶が互いに 接触しあらまで,十分に等温結晶化させ，ついで急 冷して作ったフィルムの DSC 曲線より決定され た $T_{m 2}, T_{m 3}$ は結晶化温度には汪とんど繁関係で ある。たたし， $160^{\circ} \mathrm{C}$ 以上で結晶化させる場合に は主ピークは高温にずれる可能性がある。
対応するピークであって，ピーク温度はほぼ処理温度に 等しい。

4）低温ピークを発生させるためには，少なくとも部 分融解が起こる程度まで試料を加熱する必要がある。し かし, 全結晶の $50 \%$ 以上部分融解すると，むはや低温 ピークは発生しない。

一方，結晶相としては，規則的なラメラ組織とそれ以 外の（ラメラとラメラの間にある）結晶組織とが存在す る。1 次結晶化ではまずラメラ組織が発生する。それに 続く 2 次結晶化または熱処理において, ラメラ間が結晶 化したり, ラメラの厚化が起こる。さらに, ラメラの厚 化が融解主ピークを高温にずらせることが多い（もちろ ん, ラメラの厚化と融点の向上とは無関係の場合もある が)。以上の考察より，主融解ピークをラメラの融解に 対応させることができ，低温融解ピークはラメラ間結晶 化物に原因させうる可能性がある。この推定を確かめる ためには, 今後の形態学的研究が必要である。

付 記：本論文の要旨の一部は高分于研究発表会 (1966 年 7 月, 神戸) および熱測定討論会 (1966 年 11 月, 東京) において講演した。本論文の発表を許可さ れた旭化成工業株式会社瀻維研究所長諏訪博久理事, 研究の実施にあたり有意義な討諭をして下さった同所 次長池田佐喜男博士, 同所第 8 研究室長片山健一博 士, 東京工業大学河合 微助教授に怙礼申上げる。高 分解能核磁気共鳴吸収，示差熱解析でお世話になった 当社技術研究所分析研究室拈よび島津製作所中央研究 部に感謝する。

\section{文献}

1）上出健二： 緎学誌, 22, 249 (1966)

2）上出健二，真田昌彦：高化，23，481 (1966)

3) M. Dole: Fortschrit. Hochpolym.-Forsch., 2, 221(1960)

4) B. Ke, editor: J. Polymer Sci., C, No. 6, "Thermal Analysis of High Polymers" (1964).

5) B. Ke, editor: "Newer Methods of Polymer Charactrization" Chap. 9, Interscience Pub. (1964)

6) P.E. Slade Jr., L. T. Jenkins, editors: "Technique and Methods of Polymer Evaluation," vol. 1, Dekker Inc. (1966)

7）上出健二, 稲本義彦, 大野邦夫：高化，22，597 (1965)

8）上出健二：高化，24，259（1967）

9）上出健二, 真田昌彦, 中村清昭：高化，投稿予定

10) J.B. Kinsinger, R.E. Hughes: J. Phys. Chem., 63, 2002 (1959)

11）上出健二, 稲本義彦, 大野邦夫：高化, 22,529 
(1965)

12) S. Satoh, R. Chujo, T. Ozeki, E. Nagai: J. Polymer Sci., 62, S 101 (1962)

13) F.C. Stehling: J. Polymer Sci., A2, 1815 (1964)

14) J.C. Woodbrey: J. Polymer Sci., B2, 315 (1964)

15) Y. Kato, A. Nishioka: Bull. Chem. Soc., Japan, 37, 1622 (1964)

16) S. Ohnishi, K. Nukada: J. Polymer Sci., B3, 179 (1965)

17) S. Ohnishi, K. Nukada: J. Polymer Sci., B3, 1001 (1965)

18) B. Ke: J. Polymer Sci., 42, 15 (1960)

19）吉本敏雄：高分子夏季大学テキスト，B-19 (1966年, 京都)

20）上出健二：未発表結果

21) I.M. Tochinskii, N.A. Nechitailo, A.V. Topchiev: Plasticsheski Massy, 7, 3 (1960)

22) 堀三郎, 飯田昌造, 坂見 宏, 安達敏明: 第10 回高分子討論会要旨集, 438 (1961)

23) K. Tamura, K. Nakatsuka, R. Fujishiro: Bull.
Chem. Soc. Japan, 39, 20 (1966)

24) R.F. Schwenker, Jr., R.K. Zuccarello: J. Polymer Sci., C, No. 6, 1 (1964)

25) Y. Urabe, K. Takamizawa, T. Oyama: Report Progress Polymer Sci., Japan. 8, 151 (1965)

26）池田博栄, 占部美子. 高見沢檄一郎. 尾山外茂男 : 第13回高分子討論会要旨集, 699 (1964)

27）渡辺昇, 占部美子, 高見沢橄一郎, 尾山外茂男 : 第14回高分子討論会要旨集, 389 （1965）

28）粟屋 裕：日化, 83，865（1962）

29) H.D. Keith, F.J. Padden, Jr., N.M. Walter, H.W. Wyckoff: J. Appl. Phys., 30, 1485 (1959)

30) F.J. Padden, Jr., H.D. Keith: J. Appl. Phys., 30, 1479 (1959)

31) A.T. Jones, J. M. Aizlewood, D.R. Beckett: Makrmol. Chem., 75, 134 (1964)

32）高柳素夫：私信

33）上出健二, 稲本義彦, 大野邦夫：緎学誌，23，79 (1967)

34) T. Kawai, K. Kamide et al. : Makromol Chem. 投稿中

\title{
Thermal Analysis on Unorientated Film of Isotactic Polypropylene.
}

\author{
By Kenji Kamide* and Masahiko Sanada*
}

\begin{abstract}
Thermal analysis by differential scanning calorimeter (DSC) was carried out on unorientated film of isotactic polypropylene in order to study the change in fine structure during heat-treatment. Fractions and whole polymers ranging in molecular weight from $4 \times 10^{3}$ to $4.7 \times 10^{5}$ are moulded into unorientated film by using the hot press method. It was acertained from NMR measurement on $o$-dichlorobenzene solution at $150^{\circ} \mathrm{C}$ that microtacticity was independent of molecular weight. Procedure of heat-treatment in detail was taken into consideration. From DSC thermogram, three characteristic temperatures are defined; $T_{m 1}$, temperature of onset of melting, $T_{m 2}$, temperature at which melting velocity reaches maximum, $T_{m 3}$, temperature at which the trace of crystallites melts. $T_{m s}$ from DSC diagram is in very good agreement with the peak temperature of DTA (differential thermal analysis) curve. By comparing $T_{m 3}$ with melting temperature obtained from dilatometry on welldeveloped crystals, $T_{m 3}$ is proved to be the apparent melting temperature. Melting point is very sl ightly influenced by annealing temperature except the narrow temperature range of heat-treatment, usually $150 \sim 170^{\circ} \mathrm{C}$ for polymer having molecular weight higher than $4 \times 10^{4}$, for which $160 \sim 165^{\circ} \mathrm{C}$ treatment gives maximum melting temperature. Temperature range of melting for fractions is narrower than that for whole polymers when temperature above $150^{\circ} \mathrm{C}$ is used as annealing temperature. Both $T_{m 2}$ and $T_{m s}$ change little by heat-treatment below $150^{\circ} \mathrm{C}$, but slightly increases to the saturated value at temperature above $155^{\circ} \mathrm{C}$.

Small peak or shoulder appears in DSC diagram corresponding to the heat-treatment in
\end{abstract}

* Textile Research Laboratory, Asahi Chemical Industry Co. Ltd. (Ama, Takatsuki, Osaka) 
the range $70 \sim 150^{\circ} \mathrm{C}$ not only for annealed film but also for annealed solution grown crystals. Theappearance of the small peak is independent of annealing method, heating media, duration of heat-treatment, molecular weight and it's distribution. The peak temperature is several degrees higher than the annealing temperature. It is experimentally shown that the appearance of small peak can not be ascribed to melting of portion of lower degree of microtacticity, partial melting of $\beta$-form, transition of smectic form to monoclinic one, degradation, disorientation of crystallites before melting, and that small peak may be due to the melting of thermally unstable crystallites having monoclinic form of highly isotactic chains, which are formed during heat-treatment. 